(C) The Authors, 2020. Published by Cambridge University Press. This is an Open Access article, distributed under the terms of the Creative Commons Attribution licence (http://creativecommons.org/licenses/by/4.0/), which permits unrestricted re-use, distribution, and reproduction in any medium, provided the original work is properly cited.

\title{
Effects of Spirulina platensis on insulin secretion, dipeptidyl peptidase IV activity and both carbohydrate digestion and absorption indicate potential as an adjunctive therapy for diabetes
}

\author{
J. M. A. Hannan ${ }^{1}$, Prawej Ansari², Shofiul Azam³ ${ }^{3}$ Peter R. Flatt ${ }^{2}$ and Yasser H. A. Abdel Wahab* \\ ${ }^{1}$ Department of Pharmacy, Independent University, Dhaka 1229, Bangladesh \\ ${ }^{2}$ School of Biomedical Sciences, Ulster University, Co. Londonderry, Northern Ireland BT52 1SA, UK \\ ${ }^{3}$ Department of Integrated Bioscience, Graduate School, Konkuk University, Chungju 27478, Republic of Korea
}

(Submitted 24 October 2019 - Final revision received 27 April 2020 - Accepted 4 June 2020 - First published online 10 June 2020)

Abstract

Spirulina platensis has been found to be useful in the treatment of type 2 diabetes. The present study aims to elucidate the effects of ethanol extract and butanol fraction of $S$. platensis on insulin release and glucose homoeostasis in type 2 diabetic rats, together with their mechanism of actions. In vitro and in vivo methods were used including cellular studies to determine potential role of ion channels and cAMP in the insulinotropic actions of the extracts. The ethanol extract and butanol fraction stimulated insulin release from mouse islets and pancreatic $\beta$-cells in a concentration-dependent manner. The butanol fraction also similarly stimulated insulin release from perfused rat pancreas. The insulin-releasing action was augmented by glucose, isobutylmethylxanthine, tolbutamide and a depolarising concentration of $\mathrm{KCl}$. The insulin secretory effect was attenuated with diazoxide and verapamil and by omission of extracellular $\mathrm{Ca}^{2+}$. Butanol fraction was found to significantly inhibit dipeptidyl peptidase IV enzyme activity. Moreover, butanol fraction improved glucose tolerance following oral glucose administration $(2.5 \mathrm{~g} / \mathrm{kg}$ body weight (b.w.)). The butanol fraction was tested on $24 \mathrm{~h}$ starved rats given an oral sucrose load ( $2.5 \mathrm{~g} / \mathrm{kg}$ b.w.) to examine possible effects on carbohydrate digestion and absorption. S. platensis substantially decreased postprandial hyperglycaemia after oral sucrose load and increased unabsorbed sucrose content throughout the gut. During in situ intestinal perfusion with glucose, the butanol fraction reduced glucose absorption and promoted gut motility. Finally, chronic oral administration of butanol fraction for $28 \mathrm{~d}$ significantly decreased blood glucose, increased plasma insulin, pancreatic insulin stores, liver glycogen and improved lipid profile. The characterisation of active compounds from butanol fraction revealed the presence of $p$-coumaric acid, $\beta$-carotene, catechin and other antioxidant polyphenols. In conclusion, $S$. platensis could be an adjunctive therapy for the management of type 2 diabetes.

Key words: Diabetes: Plant therapies: Glucose: Insulin

Diabetes mellitus is a metabolic syndrome where pancreatic $\beta$-cells fail to meet the body's need for insulin with resultant hyperglycaemia and increased risk of diabetic complications. The WHO recognised diabetes mellitus as the world's fastest growing metabolic disorder. Type 1 diabetes is the result of total or near-total $\beta$-cell destruction, whereas type 2 diabetes mellitus (T2DM) is the result of $\beta$-cell dysfunction and insulin resistance. About $90 \%$ of diabetic patients suffer from T2DM. This condition is associated with the alterations in the metabolism of lipids, carbohydrates and proteins ${ }^{(1)}$, which causes multiple complications including $\mathrm{CVD}^{(2)}$, retinopathy ${ }^{(3)}$, neuropathy, cognitive decline ${ }^{(4)}$, nephropathy and end-stage renal disease ${ }^{(3)}$.

T2DM treatments include diet together with either a single or combination of oral anti-hyperglycaemic agents, to manage dysglycaemia ${ }^{(5,6)}$. Although advances have been made recently in the treatment options to achieve better glycaemic control, they are often expensive and associated with notable adverse effects $^{(7,8)}$. This focuses attention particularly in poorer countries towards herbal therapy and dietary supplements as alternative approaches to the mainstream medical treatment of T2DM. Unlike contemporary treatment, herb-based medicines are entirely natural; they possess very few adverse effects and are generally affordable ${ }^{(9)}$. It has been reported that nearly $30-76 \%$ of $\mathrm{T} 2 \mathrm{DM}$ patients from different countries are using herbal medicines ${ }^{(10,11)}$ and that this approach is managing T2DM with safety ${ }^{(12)}$.

Over the last decades, functional foods received attention as a potential source of useful bioactive protein hydrolysates

Abbreviations: b.w., body weight; DPP-IV, dipeptidyl peptidase IV; GI, gastrointestinal; KRB, Krebs-Ringer bicarbonate; T2DM, type 2 diabetes mellitus.

* Corresponding author: Yasser H. A. Abdel Wahab, email y.abdel-wahab@ulster.ac.uk 
and peptides that have health benefits and reduce the risk of disease ${ }^{(13)}$. In this way, many aquatic species have been studied with the generation of new and useful bioactive peptide sources. For instance, the eukaryotic microalgae and prokaryotic cyanobacteria (often called blue-green algae) utilisation in the food industry has become globally popular ${ }^{(14,15)}$. Edible microalgal and cyanobacterial proteins have been established as suitable precursors for the production of biologically active peptides $^{(14)}$. Thus, a series of peptides isolated from microalgal or cyanobacterial hydrolysates have been demonstrated to exhibit desirable bioactivities, such as antioxidative, anticancer, anti-inflammatory and antihypertensive properties $^{(13,16-18)}$.

Spirulina platensis is a unicellular cyanobacterium belonging to the Cyanophyceae class, Oscillatoriaceae family ${ }^{(19)}$. This organism (cyanobacterium) is characterised by spiral chains of the cells enclosed in a thin sheath. It contains very potent naturally occurring antioxidants and free radical scavenging agents $^{(20)}$. S. platensis is non-toxic, bioavailable, and is believed to provide significant multiorgan protection against many drugs and chemically induced toxic assaults ${ }^{(21)}$. Active constituents exhibit anti-inflammatory, neuroprotective, hepatoprotective, immunomodulatory and anticancer activities ${ }^{(22)}$. A recent animal study reported potential anti-diabetic effects of $S$. platensis, but the mechanisms underlying such effects are unknown ${ }^{(23-25)}$. In this paper, we have made a detailed study of effects of $S$. platensis on pancreatic insulin release, dipeptidyl peptidase IV (DPPIV) inhibition and various gastrointestinal (GI) tract actions to elucidate the mechanism and therapeutic potential of $S$. platensis for improvement of diabetes control.

\section{Materials and methods}

\section{Plant material and preparation of ethanol extract}

S. platensis was purchased from Bangladesh Council of Scientific and Industrial Research, Dhaka, Bangladesh and was authenticated by a botanical taxonomist. A voucher specimen was deposited in the Bangladesh National Herbarium (Mirpur, Dhaka). The whole plants were dried at $40^{\circ} \mathrm{C}$ (oven) and processed into fine powder by a cyclotec grinding machine. The powder $(2 \mathrm{~kg})$ was extracted with $80 \%$ ethanol (10 litres) in a conical flask and put into an orbital shaker $(550 \mathrm{rpm}, 48-$ $72 \mathrm{~h}$ ). The extract was filtered using a Whatman filter paper, and ethanol was removed using a rotary evaporator (Fig. 1). A Varian 801 LY-3-TT freeze dryer (Varian) was used to freezedry the extract which was stored at $4^{\circ} \mathrm{C}$ until used.

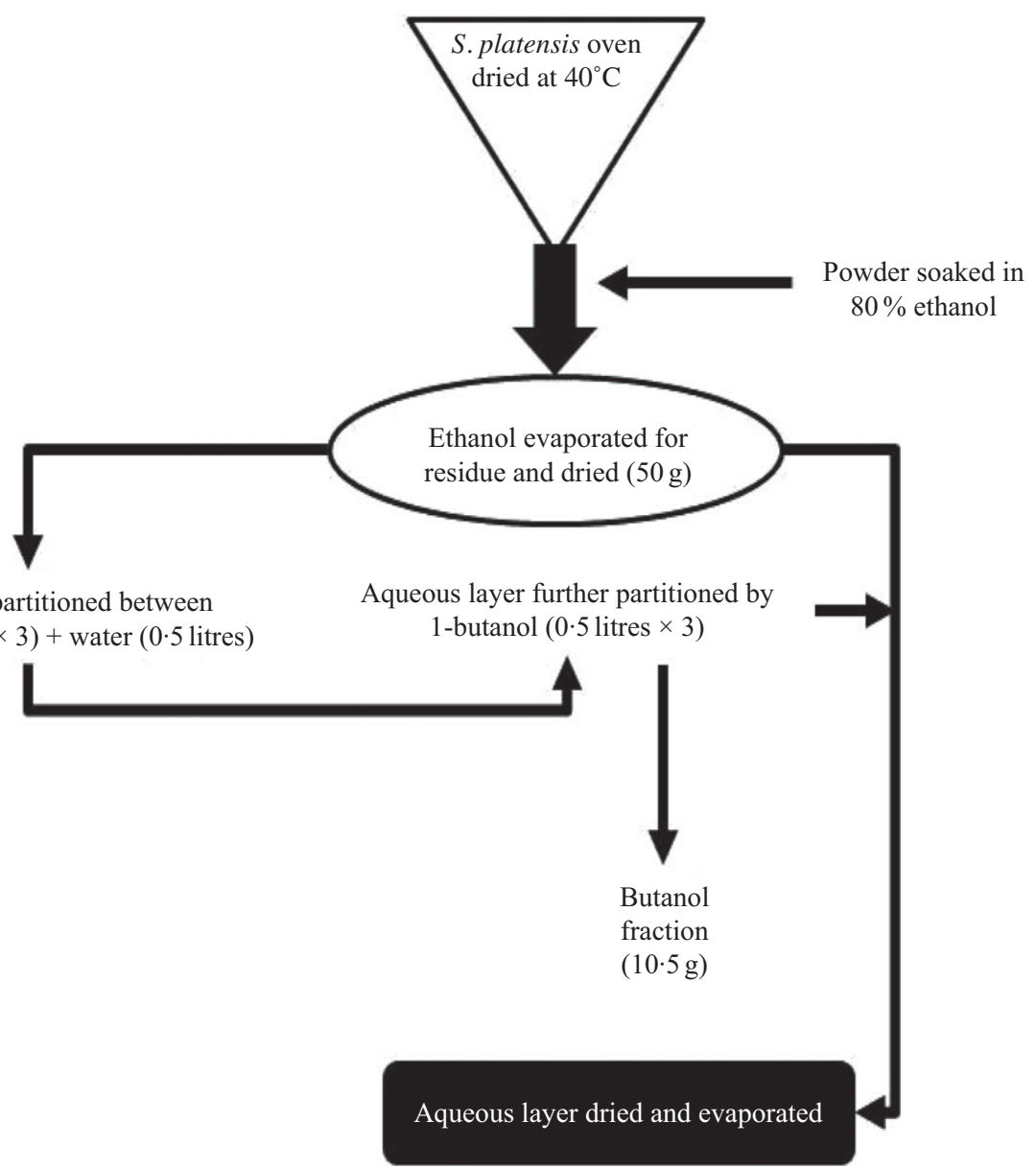

Fig. 1. Schematic diagram of preparation of ethanol extract and butanol partition fraction of Spirulina platensis. 
Preparation of butanol fraction of Spirulina platensis

According to the previously described method ${ }^{(26)}$, the ethanol extract $(50 \mathrm{~g})$ was partitioned into hexane $(0.5$ litres $\times 3)$ and water $(0.5$ litres). Hexane fraction was separated, and soluble material $(15 \mathrm{~g})$ was isolated after evaporation to dryness. The water layer was additionally partitioned using 1-butanol ( 0.5 litres $\times 3$ ), and soluble materials of 1-butanol $(10.5 \mathrm{~g})$ were obtained after evaporation to dryness. The leftover watery portion was further concentrated using a rotary evaporator, and the end product was dried ( $20 \mathrm{~g}$ ) using a freeze dryer and stored in a refrigerator at $4^{\circ} \mathrm{C}$ until used (Fig. 1). The ethanol extract and butanol fraction were analysed for bioactivity in the present studies.

\section{Insulin secretion from isolated islets and $\beta$-cell lines}

The effects of $S$. platensis on insulin release from BRIN-BD11 cells and isolated mouse islets were assessed as described previously $^{(27)}$. A range of concentrations of plant extract or butanol fraction or known modulators of insulin secretion were incubated with BRIN-BD11 cells in the presence or absence of glucose $(1 \cdot 1,5.6$ or $16.7 \mathrm{~mm})$ during 40 - or 20 -min incubation at $37^{\circ} \mathrm{C}$. Islets were isolated from the pancreas of NIH Swiss mice $^{(27)}$. Groups of ten islets were cultured for $24-48 \mathrm{~h}$ in Roswell Park Memorial Institute (RPMI) media prior to pre-incubation in Krebs-Ringer bicarbonate (KRB) buffer at $1.4 \mathrm{~mm}$ glucose for $60 \mathrm{~min}$. Test incubations were performed in the presence of $16.7 \mathrm{~mm}$ glucose for $60 \mathrm{~min}$. After incubation, the supernatants were collected and stored at $-20^{\circ} \mathrm{C}$ until analysed by insulin radioimmunoassay ${ }^{(28)}$.

\section{Insulin secretion from perfused pancreas}

Long-Evans male rats (180-250 g body weight (b.w.)) were anaesthetised with sodium-pentobarbital $(50 \mathrm{mg} / \mathrm{kg}$, intraperitoneal), and the pancreas was isolated and perfused at $37^{\circ} \mathrm{C}$ according to the method of Giroix et al. ${ }^{(29)}$. KRB buffer supplemented with $1.25 \mathrm{~g} / 1$ bovine serum albumin and $40 \mathrm{~g} / \mathrm{l}$ dextran T70 and 2.8- or 11·2-mm glucose. A mixture of $\mathrm{O}_{2}-\mathrm{CO}_{2}$ (95:5) was continuously used to gas the perfusate. The composition of the perfusate was changed after the first $20 \mathrm{~min}$ of equilibration as indicated in Fig. 3. Samples were stored at $-20^{\circ} \mathrm{C}$ prior to measurement of insulin using ELISA kits supplied by Crystal Chem.

\section{Membrane potential and intracellular calcium $\left(\left[\mathrm{Ca}^{2+}\right]_{i}\right)$}

The effects of $S$. platensis on membrane potential and intracellular Ca were measured using BRIN-BD11 cell monolayers as previously described ${ }^{(30,31)}$. Cells were seeded onto ninety-six-well plates (black-walled, clear-bottomed microplates, Greiner) and washed with KRB buffer prior to the addition of FLEX assay reagents (Molecular Devices). Effects of introducing extract or butanol fraction and other reagents were monitored fluorometrically using Flex Station 3 (Molecular Devices) at wavelengths of 450 and $525 \mathrm{~nm}$, respectively.

\section{Dipeptidyl peptidase IV activity}

Effects of $S$. platensis on DPP-IV enzyme activity were determined using a fluorometric method. Enzyme activity was determined using ninety-six-well black-walled, clear-bottomed microplates (Greiner) containing $8 \mathrm{mU} / \mathrm{ml}$ of DPP-IV enzyme and $200 \mu \mathrm{M}$ of substrate (Gly-Pro-AMC) as described previously ${ }^{(32)}$. Flex Station 3 (Molecular Devices) was used to measure the changes in fluorescence with an excitation and emission at 370 and $440 \mathrm{~nm}$ with $2.5 \mathrm{~nm}$ slit width, respectively.

\section{Induction of experimental diabetes}

Long-Evans male rats (150-200 g) were purchased from the International Center for Diarrheal Disease Research, Bangladesh. Standard environmental conditions with temperature of $22(\operatorname{SEM~} 5)^{\circ} \mathrm{C}$, relative humidity of $55-65 \%$ and $12 \mathrm{~h}$ light-12 h dark cycle were maintained. Food and fresh water were supplied ad libitum. The composition of the pelleted diet (metabolisable energy of $11.8 \mathrm{MJ} / \mathrm{kg}$ per $2820 \mathrm{kcal} / \mathrm{kg}$ ) was described previously ${ }^{(33)}$. T2DM was induced in neonatal rats at $2 \mathrm{~d}$ of age by a single intraperitoneal injection of streptozotocin (90 mg/kg b.w.). T2DM rats were selected for the experiments at 12 weeks of age after an oral glucose tolerance test. Animals exhibiting blood glucose levels of $8-12 \mathrm{mmol} / \mathrm{l}$ were chosen as type 2 diabetes rats. The 'Principles of Laboratory Animals Care' (National Institutes of Health Publication no. 86-23, revised 1985) and the UK Animals Scientific Procedures Act 1986 were followed.

\section{Residual gut sucrose content}

The effects of $S$. platensis on sucrose digestion and absorption from the GI tract were assessed after the oral administration of sucrose solution ( $2.5 \mathrm{~g} / \mathrm{kg}$ b.w.) to 24 -h fasted T2DM rats with or without butanol fraction of $S$. platensis $(250 \mathrm{mg} / \mathrm{kg}$, b.w.). Blood samples were collected from the tip of the tail prior to and after 30, 60, 120 and $240 \mathrm{~min}$ for glucose analysis. To measure the unabsorbed sucrose content of the GI tract, rats were killed at the same time points and the tract was excised and divided into six parts: the stomach, the upper $(20 \mathrm{~cm})$, middle and lower $(20 \mathrm{~cm})$ of the small intestine, the caecum and the large intestine. Each segment was washed with acidified ice-cold saline and centrifuged for $10 \mathrm{~min}$ at $3000 \mathrm{rpm}(1000 \mathrm{~g})$. The resulting supernatant was boiled for $2 \mathrm{~h}$ to hydrolyse the sucrose, and $\mathrm{pH}$ was adjusted (7.0-7.4) by adding $\mathrm{NaOH}$. The concentration of serum glucose and the total amount of glucose liberated from GI tract were determined ${ }^{(34)}$.

\section{Intestinal glucose absorption}

The effects of $S$. platensis on intestinal glucose absorption were determined using an in situ intestinal perfusion technique ${ }^{(35)}$. Non-diabetic rats were fasted for $36 \mathrm{~h}$ followed by induction of anaesthesia with sodium pentobarbital ( $50 \mathrm{~g} / \mathrm{kg}$ b.w.). Butanol fraction of $S$. platensis $(5 \mathrm{mg} / \mathrm{ml}$ equal to $0.25 \mathrm{~g} / \mathrm{kg}$ ) dissolved in KRB buffer containing glucose ( $54 \mathrm{~g} / \mathrm{l})$ was infused via the rat pylori, and perfusate was collected at the end of ileum. 
The control group was treated with KRB buffer only in the presence of glucose. Perfusion of intestine was carried out at a constant rate of $0.5 \mathrm{ml} / \mathrm{min}$ for $30 \mathrm{~min}$ at $37^{\circ} \mathrm{C}$. The results were expressed as the percentage of glucose absorbed, measured from the amount of glucose in solution before and after the perfusion of intestine.

\section{Intestinal disaccharidase activity and gastrointestinal motility}

Intestinal disaccharidase enzyme activity was determined as described previously ${ }^{(33)}$. Non-diabetic rats were fasted for $20 \mathrm{~h}$ followed by the oral administration of $S$. platensis $(250 \mathrm{mg} / \mathrm{kg}$ ) or water alone. The rats were killed after $1 \mathrm{~h}$, and the small intestine was collected, cut longitudinally and rinsed with ice-cold saline. Volume was made up to $10 \mathrm{ml}$ by adding saline $(0.9 \%$ $\mathrm{NaCl}$ ), and the tissue was homogenised. Aliquots of the homogenate were incubated at $37^{\circ} \mathrm{C}$ in a $40 \mathrm{~mm}$ sucrose solution for $60 \mathrm{~min}$. Disaccharidase enzyme activity was measured as $\mu \mathrm{mol} / \mathrm{mg}$ protein per $\mathrm{h}$. Acarbose $(200 \mathrm{mg} / \mathrm{kg})$, an established disaccharidase enzyme inhibitor, was used as a control. GI motility was measured according to the method of Chatterjee ${ }^{(36)}$. The butanol fraction of $S$. platensis $(250 \mathrm{mg} / \mathrm{kg} \mathrm{b.w.)} \mathrm{or} \mathrm{water}(10 \mathrm{ml} /$ $\mathrm{kg}$ ) was administered orally to non-diabetic rats. One hour later, a suspension of $\mathrm{BaSO}_{4}$ milk $\left(10 \% \mathrm{BaSO}_{4}\right.$ and $0.5 \%$ carboxymethyl cellulose; w/v) was administered orally. Rats of both groups were killed after $15 \mathrm{~min}$ of administration of $\mathrm{BaSO}_{4}$. The length travelled by $\mathrm{BaSO}_{4}$ milk was calculated and expressed as the percentage of the total distance of the small intestine (pylorus to the ileo-caecal junction). The established drugs: Loperamide $(5 \mathrm{mg} / \mathrm{kg}$ b.w.) and Sennoside $(10 \mathrm{mg} / \mathrm{kg}$ b.w.) were used as positive controls.

\section{Glucose tolerance and chronic effects in type 2 diabetic} rats

The effects of butanol fraction of S. platensis on oral glucose tolerance were measured after fasting the T2DM rats for $12 \mathrm{~h}$. Blood samples were obtained from the cut tip of the tail at given time points $(0,30,60,120$ and $180 \mathrm{~min})$ before and after oral administration of glucose $(2.5 \mathrm{~g} / \mathrm{kg}$ b.w.) with (Treated group) or without (Control group) S. platensis $(250 \mathrm{mg} / \mathrm{kg}$ ). The long-term effects of $S$. platensis on glucose homoeostasis in T2DM rats were measured by twice daily administration (oral gavage) of butanol fraction $(250 \mathrm{mg} / \mathrm{kg}$ ) for $28 \mathrm{~d}$. Control rats received oral administration of water alone. Blood samples were collected, and serum was separated by centrifugation and stored at $-20^{\circ} \mathrm{C}$ until measurement of glucose, insulin and lipid profiles. Glucose and insulin were measured via the glucose oxidasephenol amino phenazone (GOD-PAP) method (glucose kit, Randox $^{\mathrm{TM}}$ ) and rat insulin ELISA Kit (Crystal Chem ${ }^{\mathrm{TM}}$ ), respectively.

\section{Effects of Spirulina platensis on liver glycogen content}

The effects of Spirulina platensis treatment for $28 \mathrm{~d}$ on liver glycogen content were determined as previously described ${ }^{(37)}$. Briefly, the weight of liver was measured and finely homogenised with $10 \mathrm{ml}$ of $5 \%$ trichloroacetic acid. The precipitated proteins were filtered, and glycogen content was analysed from the clear filtrate. One millilitre of the filtrate was mixed with $2 \mathrm{ml}$ of $10 \mathrm{~N} \mathrm{KOH}$ and boiled for $1 \mathrm{~h}$ at $100^{\circ} \mathrm{C}$. After cooling, $1 \mathrm{ml}$ of glacial acetic acid was added and the solution was made up to $10 \mathrm{ml}$ by adding deionised water. Then, $1 \mathrm{ml}$ of this solution was mixed on ice with $2 \mathrm{ml}$ of anthrone solution (100 mg anthrone dissolved in $50 \mathrm{ml}$ of concentrated $\mathrm{H}_{2} \mathrm{SO}_{4}$ ) ; this mixture was boiled for additional $10 \mathrm{~min}$ at $100^{\circ} \mathrm{C}$ and then cooled. Aliquots were taken in a microplate reader, and the absorbance was measured at $490 \mathrm{~nm}$.

\section{Insulin content in pancreases}

Rats were killed after $28 \mathrm{~d}$ treatment with S. platensis (250 mg/ $\mathrm{kg}$ ), and the pancreatic tissues were dissected, weighed, homogenised and extracted in $(10 \mathrm{ml})$ acid alcohol solution $(23.5 \%$ distilled water, $75 \%$ ethanol and $1.5 \% \mathrm{HCl} 12 \mathrm{~mm}$ ). After centrifugation, the supernatant samples were stored at $-20^{\circ} \mathrm{C}$. Pancreatic insulin level was determined using rat insulin ELISA Kit (Crystal Chem $\left.^{\mathrm{TM}}\right)$.

\section{Chemical characterisation by reversed-phase HPLC}

Crude extract was re-dissolved in solvent A ( $0 \cdot 12 \%(\mathrm{v} / \mathrm{v})$ trifluoroacetic acid (TFA)-water) and purified by reversed-phase HPLC. The prepared crude extract solution was injected in to a Vydac 218TP1022 (C-18) reversed-phase HPLC column (Grace) equilibrated with $0 \cdot 12 \%(\mathrm{v} / \mathrm{v})$ TFA/water at a flow rate of $1.0 \mathrm{ml} / \mathrm{min}$. The concentration of acetonitrile within the eluting solvent was expanded using linear gradients 0 to $20 \%$ over $10 \mathrm{~min}$ and to $70 \%$ over a period of $25 \mathrm{~min}$. The wavelengths of 254 and $360 \mathrm{~nm}$ were used to measure the absorbance.

\section{Statistical analysis}

Statistical analyses were performed by using SPSS for windows (version 20). The results are represented as mean values with their standard errors. Data were analysed using repeatedmeasures ANOVA followed by Dunnett's adjustment and unpaired $t$ test where applicable. $P<0.05$ was considered as the level of significance.

\section{Results \\ Effects of Spirulina platensis on insulin secretion from clonal pancreatic $\beta$-cells (BRIN BD11)}

Fig. 2(a) and (b) shows the effects of ethanol extract and butanol fraction of $S$. platensis on insulin secretion from BRIN-BD11 cells. Alanine $(10 \mathrm{~mm})$ was used as a positive control. Both extract and fraction $(1 \cdot 6-5000 \mu \mathrm{g} / \mathrm{ml})$ stimulated insulin release concentrations dependently compared with control $(5.6 \mathrm{~mm}$ glucose). Higher concentrations $(1000-5000 \mu \mathrm{g} / \mathrm{ml})$ also induced insulin release but were associated with decreased cell viability. Further tests revealed that the insulinotropic effects of a nontoxic dose of $S$. platensis $(40 \mu \mathrm{g} / \mathrm{ml})$ were significantly enhanced in the presence of $16.7 \mathrm{~mm}$ glucose $(P<0.001)$, isobutyl-methyl xanthine $(P<0.001)$ and tolbutamide $(P<0.001$, Fig. 2(e) and (f)). The phosphodiesterase inhibitor isobutyl-methyl xanthine and tolbutamide were used to modulate the glucose- 
(a)

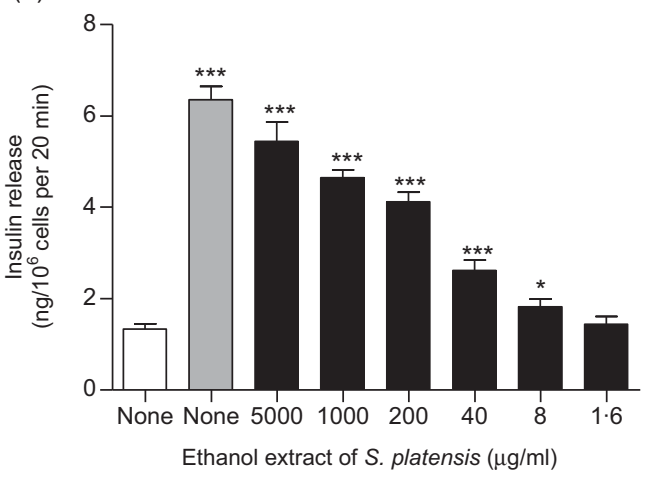

(c)

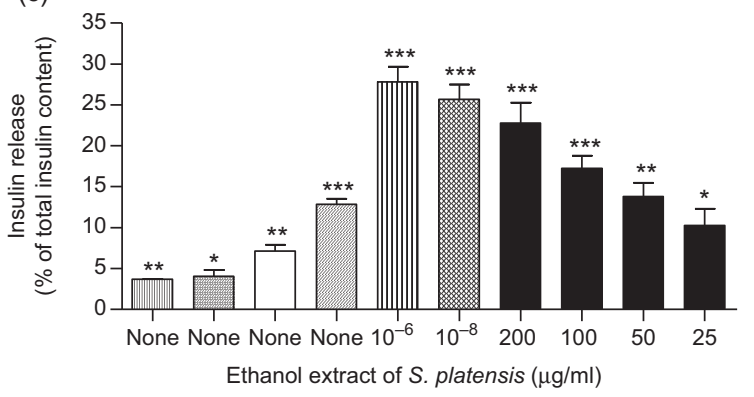

(b)

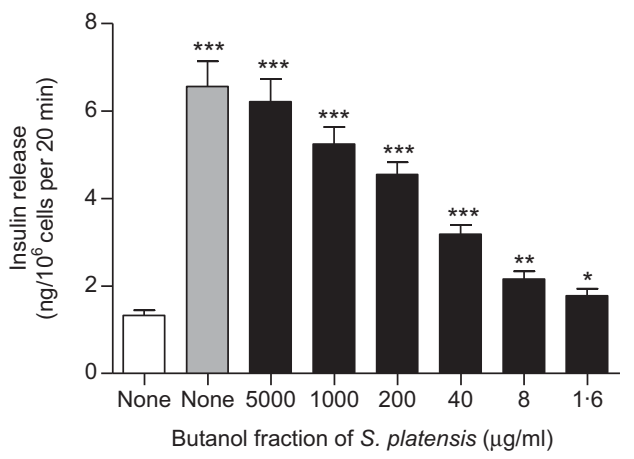

(d)

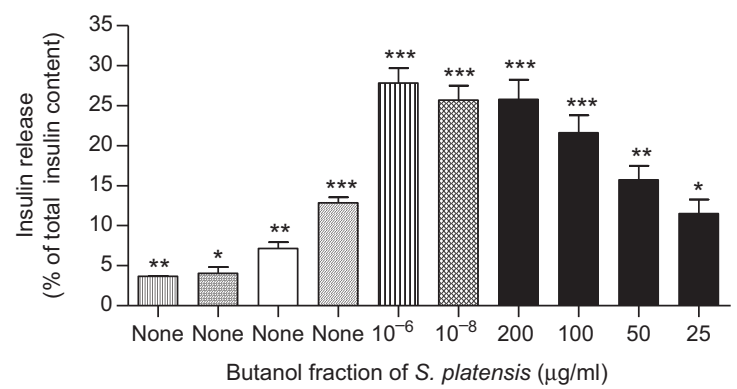

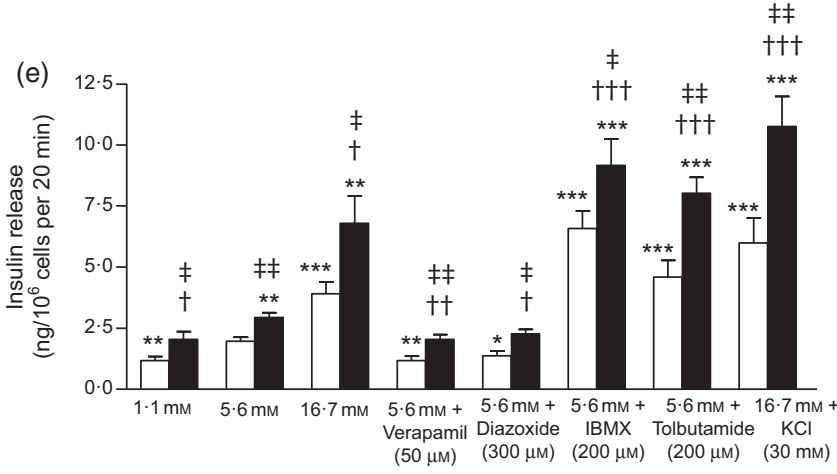

Additions

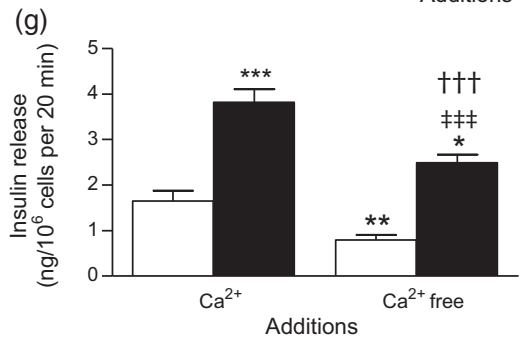

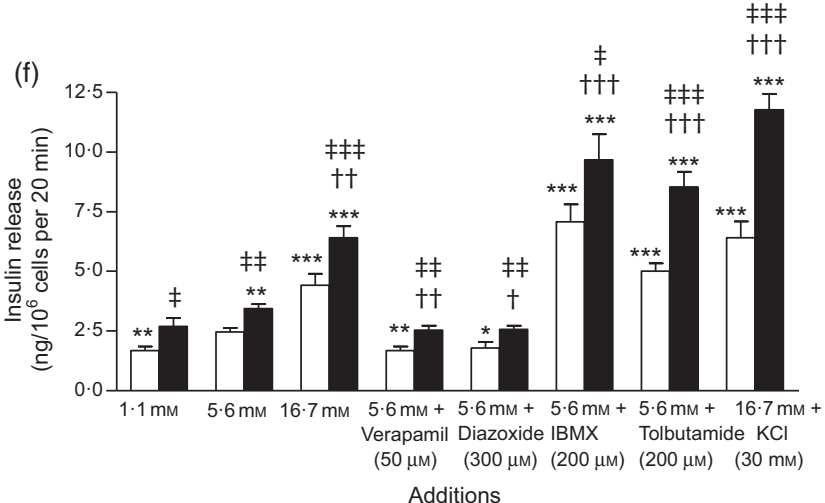

(h)

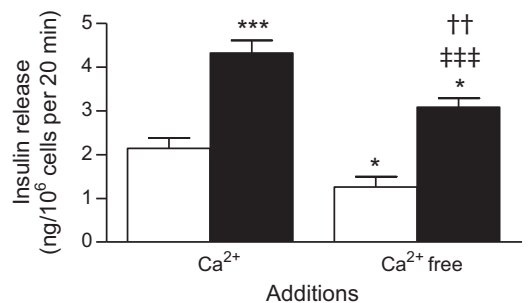

Fig. 2. Effects of ethanol extract and butanol fraction of Spirulina platensis on insulin release from (a and b) BRIN-BD11 cells, (c and d) islets of Langerhans and (e-h) BRIN-BD11 cells in the presence of established stimulators or inhibitors of insulin secretion. Values are means with their standard errors, $n 8$ and 4 for insulin release. ${ }^{*} P<0.05$, ${ }^{* *} P<0.01$, ${ }^{* *} P<0.001$ compared with 5.6 and $16.7 \mathrm{~mm}$ glucose alone. $+P<0.05$, t† $P<0.01$ and + $P=0.001$ compared with 5.6 mm glucose in the presence of the extract or fraction. $\ddagger P<0.05$, $\ddagger \ddagger P<0.001$, $¥ \ddagger \ddagger P<0.001$ compared with respective incubation in the absence of the extract or fraction. (a) $\square, 5.6 \mathrm{~mm}$ glucose; $\square, 5.6 \mathrm{~mm}$ glucose $+10 \mathrm{~mm}$ alanine; $\quad, 5.6 \mathrm{~mm}$ glucose + ethanol extract $(\mu \mathrm{g} / \mathrm{ml})$. (b) $\square, 5.6 \mathrm{~mm}$ glucose; $\square, 5.6 \mathrm{~mm}$ glucose $+10 \mathrm{~mm}$ alanine; $\square, 5.6 \mathrm{~mm}$ glucose + butanol fraction ( $\mu \mathrm{g} / \mathrm{ml})$. (c) $\square, 1.4 \mathrm{~mm}$ glucose; $\square, 5.6 \mathrm{~mm}$ glucose; $\square, 16.7 \mathrm{~mm}$ glucose; $\square, 10 \mathrm{~mm}$ alanine; 血西, $16.7 \mathrm{~mm}$ glucose + glucagon-like peptide 1 (м); $\square, 16.7 \mathrm{~mm}$ glucose + ethanol extract ( $\mu \mathrm{g} / \mathrm{ml})$. (d) $\square, 1.4 \mathrm{~mm}$ glucose; $\square, 5.6 \mathrm{~mm}$ glucose; $\square, 16.7 \mathrm{~mm}$ glucose; $\square, 10 \mathrm{~mm}$ alanine; 而盂, $16.7 \mathrm{~mm}$ glucose + glucagon-like peptide 1 (м);, $16.7 \mathrm{~mm}$ glucose + butanol fraction ( $\mu \mathrm{g} / \mathrm{ml})$. (e) $\square$, Glucose alone; $\square$, glucose + ethanol extract $(40 \mu \mathrm{g} / \mathrm{ml})$. (f) $\square$, Glucose alone; $\square$, glucose + butanol fraction (40 $\mu \mathrm{g} / \mathrm{ml})$. (g) $\square$, Glucose (5.6 mm); $\square$, glucose (5.6 mM) + ethanol extract $(40 \mu \mathrm{g} / \mathrm{ml})$. (h) $\square$, Glucose $(5.6 \mathrm{~mm})$; $\square$, glucose $(5.6 \mathrm{~mm})+$ butanol fraction $(40 \mu \mathrm{g} / \mathrm{ml})$. 
(a)

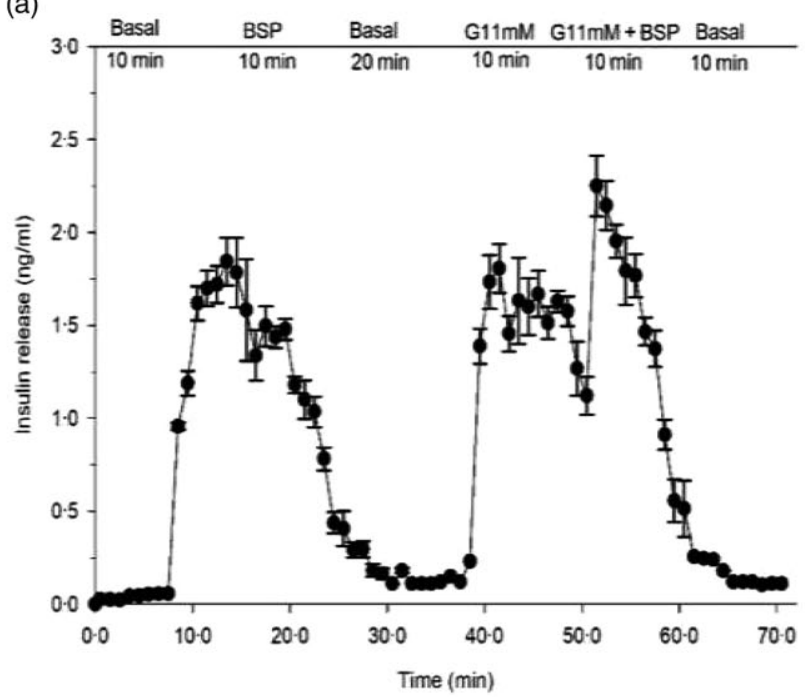

(c) Basal G11mM G11mM + BSP Basal $\mathrm{G} 11 \mathrm{mM}+\mathrm{BSP}+$ Verapamil Basal

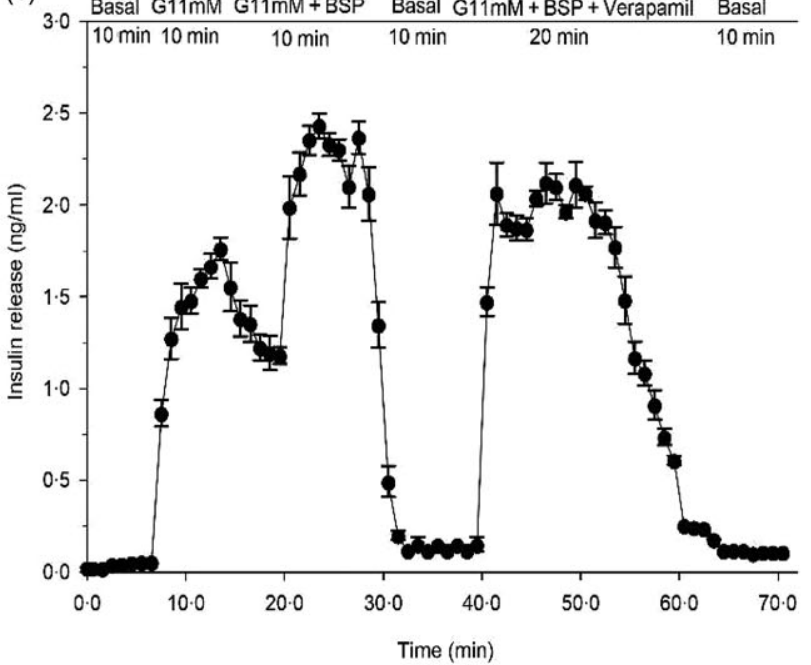

(b)

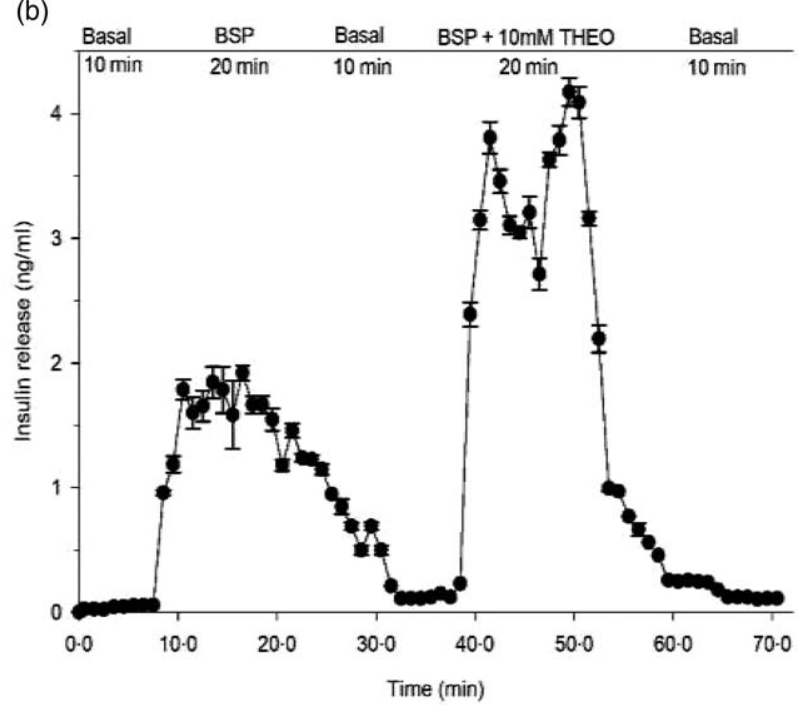

(d) Basal G11mM G11mM+BSP Basal G11mM + BSP + Diazoxide Basal

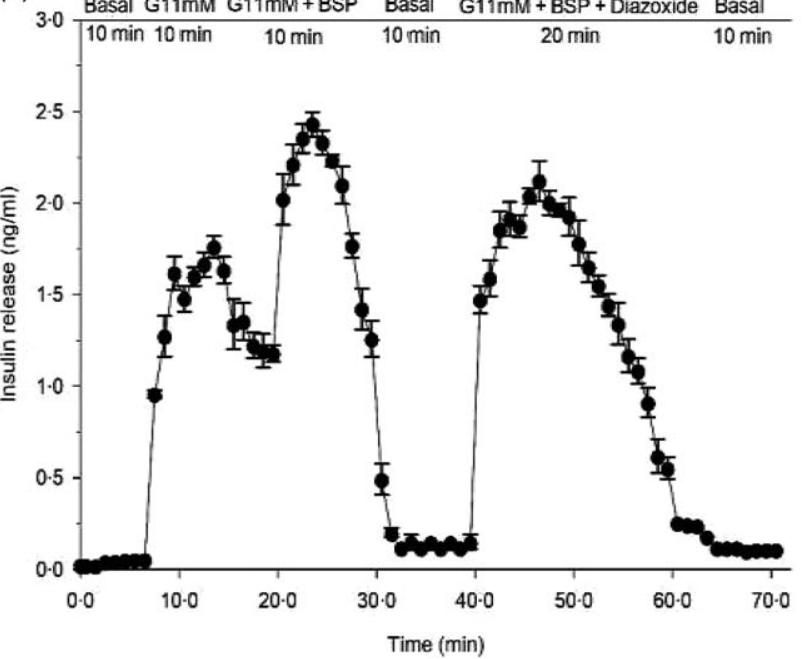

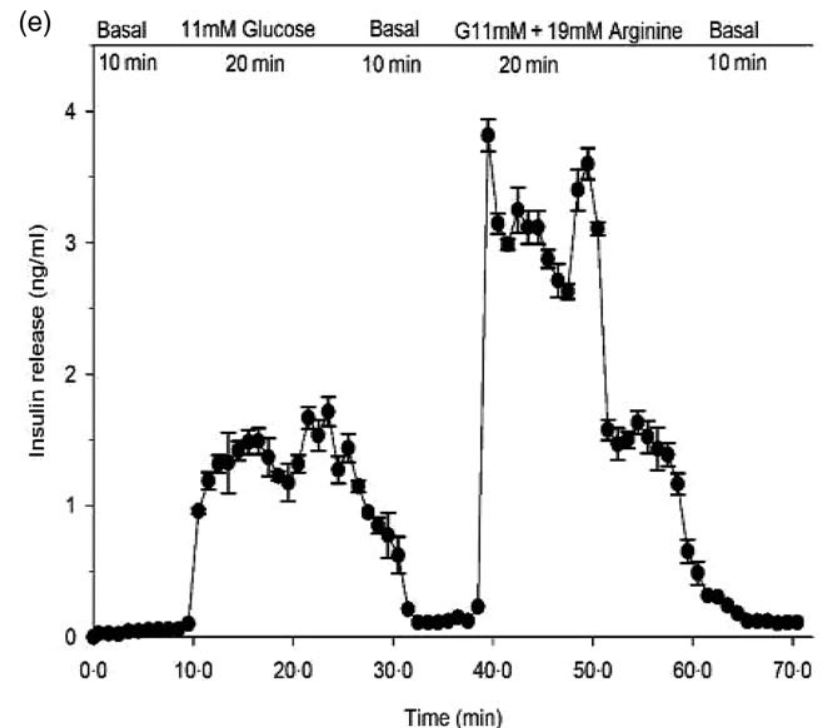

Fig. 3. Effects of butanol fraction of Spirulina platensis on insulin release from perfused rat pancreas in the (a) absence or (b) presence of theophylline (10 mm), (c) verapamil $(50 \mu \mathrm{M})$ and $(\mathrm{d})$ diazoxide $(8 \mathrm{~mm})$ at $11 \mathrm{~mm}$ glucose and $(\mathrm{e})$ control group: arginine $(19 \mathrm{~mm})$ alone. Values are means with their standard errors, $n 4$. Pancreas was perfused $(1 \mathrm{ml} / \mathrm{min}$ ) with butanol fraction of $S$. platensis at a dose of $5 \mathrm{mg} / \mathrm{ml}$ in the presence or absence of theophylline (10 mm), verapamil (50 $\mu \mathrm{m}$ ) and diazoxide $(8 \mathrm{~mm})$ at $11 \mathrm{~mm}$ glucose and control group: arginine $(19 \mathrm{~mm})$ alone. The glucose concentration was raised from the basal level of $2.8 \mathrm{~mm}$ (basal) to $11 \mathrm{~mm}$. G, glucose, THEO, theophylline; BSP, butanol fraction of $S$. platensis. 
induced cAMP production and insulin secretion. In contrast, the effects of both ethanol extract and butanol fraction of $S$. platensis were inhibited by $40-50 \%$ by diazoxide $(P<0.05)$ and verapamil $\left(P<0 \cdot 01\right.$, Fig. 2(e) and (f)). Both diazoxide, a $\mathrm{K}_{\mathrm{ATP}}$ channel opener and verapamil, voltage-gated $\mathrm{Ca}$ channel blocker inhibited pancreatic insulin secretion by reducing intracellular $\mathrm{Ca}^{2+}$ influx. The ethanol extract and butanol fraction also maintained an ability to increase insulin secretion in cells depolarised with $30 \mathrm{~mm} \mathrm{KCl}\left(P<0.001\right.$, Fig. 2(e) and (f)). Absence of $\mathrm{Ca}^{2+}$ (Fig. $2(\mathrm{~g})$ and $(\mathrm{h})$ ) significantly inhibited but did not totally abolish insulin secretion induced by $S$. platensis.

\section{Effects of Spirulina platensis on insulin secretion from isolated islets}

The ethanol extract and butanol fraction significantly increased insulin secretion from isolated mouse islets compared with $16.7 \mathrm{~mm}$ glucose alone $(P<0.05-P<0.001$; Fig. $2(\mathrm{c})$ and (d) $)$. Increasing the concentrations from 25 to $200 \mu \mathrm{g} / \mathrm{ml}$ resulted in 2 - and 2.5 -fold increase in insulin release compared with control (16.7 mu glucose); glucagon-like peptide $1\left(10^{-6}\right.$ and $\left.10^{-8} \mathrm{M}\right)$ and alanine $(10 \mathrm{~mm})$ were used in this experiment as positive control (Fig. 2(c) and (d)).

\section{Effects of Spirulina platensis on insulin secretion from} perfused pancreas

In a pilot study, the pancreas retained insulin secretory capacity during $70 \mathrm{~min}$ with exposure to glucose and arginine (Fig. 3(e)). Butanol fraction of $S$. platensis produced a significant $(P<0 \cdot 001)$ biphasic increase in insulin release with a 20 -fold elevation above the basal level (2.8 mM) (Fig. 3(a)). Subsequent exposure for $10 \mathrm{~min}$ to $11 \mathrm{~mm}$ glucose caused a sharp rise of insulin release from the basal level of $0.05-0.01 \mathrm{ng} / \mathrm{ml}$ to a peak of $2.4-1.5 \mathrm{ng} /$ $\mathrm{ml}(P<0.001)$. After adding butanol fraction to $11 \mathrm{~mm}$ glucose, a further enhancement in insulin release was noted (Fig. 3(a)), which opposed the decline in insulin release under the continuous exposure to $11 \mathrm{~mm}$ glucose alone. Theophylline (10 $\mathrm{mm})$ is a methylxanthine derivative that inhibits cyclic nucleotide phosphodiesterase and increases the intracellular cyclic $3^{\prime}, 5^{\prime}$-AMP level. Addition of theophylline $(10 \mathrm{~mm})$ to butanol fraction increased insulin secretion further (Fig. 3(b)). As shown in Fig. 3(c) and (d), perfusion in the presence of verapamil and diazoxide at $11 \mathrm{~mm}$ glucose decreased insulin releasing activity of the butanol fraction by $20-30 \%$.

Effects of Spirulina platensis on membrane potential and intracellular calcium $\left(\left[\mathrm{Ca}^{2+}\right]_{i}\right)$ in the clonal BRIN-BD11 cell line

The ethanol extract and butanol fraction of S. platensis increased membrane potential and intracellular $\mathrm{Ca}\left(\left[\mathrm{Ca}^{2+}\right]_{\mathrm{i}}\right)$ at the presence of $5.6 \mathrm{~mm}$ glucose $(P<0.05$; Fig. $4(\mathrm{a}-\mathrm{h}))$ as compared with control $(5.6 \mathrm{~mm}$ glucose alone). $\mathrm{KCl}(30 \mathrm{~mm})$ and alanine $(10 \mathrm{~mm})$ were used as positive controls in this experiment.

Effects of Spirulina platensis on dipeptidy/ peptidase IV activity in vitro

The butanol fraction significantly $(P<0.05, \quad P<0.01$ and $P<0 \cdot 001)$ inhibited the liberation of 7-amino-4-methylcoumarin, by $7-70 \%$ at concentrations of $200-5000 \mu \mathrm{g} / \mathrm{ml}$ (Fig. 5(f)). Sitagliptin, as an established DPP-IV inhibitor, reduced DPP-IV activity by $10-97 \%(P<0.05, P<0.01$ and $P<0.001$; Fig. $5(\mathrm{e}))$ at concentrations between $16 \times 10^{-4}$ to $5 \mu \mathrm{m}$.

\section{Effects of Spirulina platensis on unabsorbed sucrose content in the gut}

At $1 \mathrm{~h}$ following sucrose load $(2.5 \mathrm{~g} / \mathrm{kg}$ b.w.), a significant $(P<0.05-0.01)$ amount of sucrose was measured in the stomach and the upper, middle, lower and large intestine (Fig. 6(a-f)). An extensive $(P<0.01)$ amount of sucrose found in the stomach, upper and middle intestine at $30 \mathrm{~min}$, while at $2 \mathrm{~h}(P<0.05)$, increased amounts of unabsorbed sucrose were measured in caecum and lower intestine. The administration of butanol fraction $(250 \mathrm{mg} / \mathrm{kg}$ b.w.) with sucrose reduced sucrose absorption significantly $(P<0 \cdot 01)$ after $30 \mathrm{~min}$ and up to $2 \mathrm{~h}$ (Fig. 6). At $4 \mathrm{~h}$, sucrose content was almost nil throughout the GI tract, although a small fraction remained in the caecum and lower intestine, indicating rapid hydrolysis and absorption of sucrose in the upper part of the intestine (Fig. 6).

\section{Effects of Spirulina platensis on intestinal glucose absorption}

During perfusion, the extent of glucose absorption in the intestine was almost consistent over $30 \mathrm{~min}$. However, supplementation with butanol fraction significantly decreased intestinal glucose absorption $(P<0.05-P<0.01)$ as illustrated in Fig. $7($ a) and (b)

\section{Effects of Spirulina platensis on intestinal disaccharidase activity and gastrointestinal motility}

Butanol fraction of $S$. platensis ( $250 \mathrm{mg} / \mathrm{kg}$ b.w.) did not affect disaccharidase enzyme activity (Fig. 7(c)). However, this fraction significantly promoted gastrointestinal motility $\quad(P<0.05$, Fig. $7(d)$ ).

\section{Acute and chronic effects of Spirulina platensis on glucose homoeostasis in type 2 diabetic rats}

Oral administration of butanol fraction of $S$. platensis $(250 \mathrm{mg} / \mathrm{kg}$ b.w.) together with glucose $(2.5 \mathrm{~g} / \mathrm{kg}$ b.w.) improved glucose tolerance at 30 and $60 \mathrm{~min}(P<0.01-P<0.05)$ in T2DM rats (Fig. 5(a) and (b)). In addition, S. platensis $(250 \mathrm{mg} / \mathrm{kg}$ b.w.) treatment lowered serum glucose significantly after sucrose load $(P<0.05$; Fig. 5(c) and (d) $)$ at 60 and $120 \mathrm{~min}$ in T2DM rats.

Furthermore, twice daily oral administration of the butanol fraction of $S$. platensis $(250 \mathrm{mg} / \mathrm{kg}$ b.w.) for $28 \mathrm{~d}$ significantly lowered serum glucose levels $(P<0.05)$ and increased serum insulin level $(P<0.05)$ compared with controls (Table 1$)$. Pancreatic insulin and liver glycogen were increased $(P<0.05)$ as shown in Table 1. Measurement of lipid profile showed that the butanol fraction of $S$. platensis $(250 \mathrm{mg} / \mathrm{kg}$ b.w.) increased HDL, while the LDL and total cholesterol were significantly decreased $(P<0 \cdot 05-0 \cdot 01$; Table 1$)$.

\section{Chemical characterisation by reversed-phase HPLC}

The phytochemical screening of butanol fraction by HPLC (Fig. 8) revealed the presence of $\beta$-carotene, catechin and some 

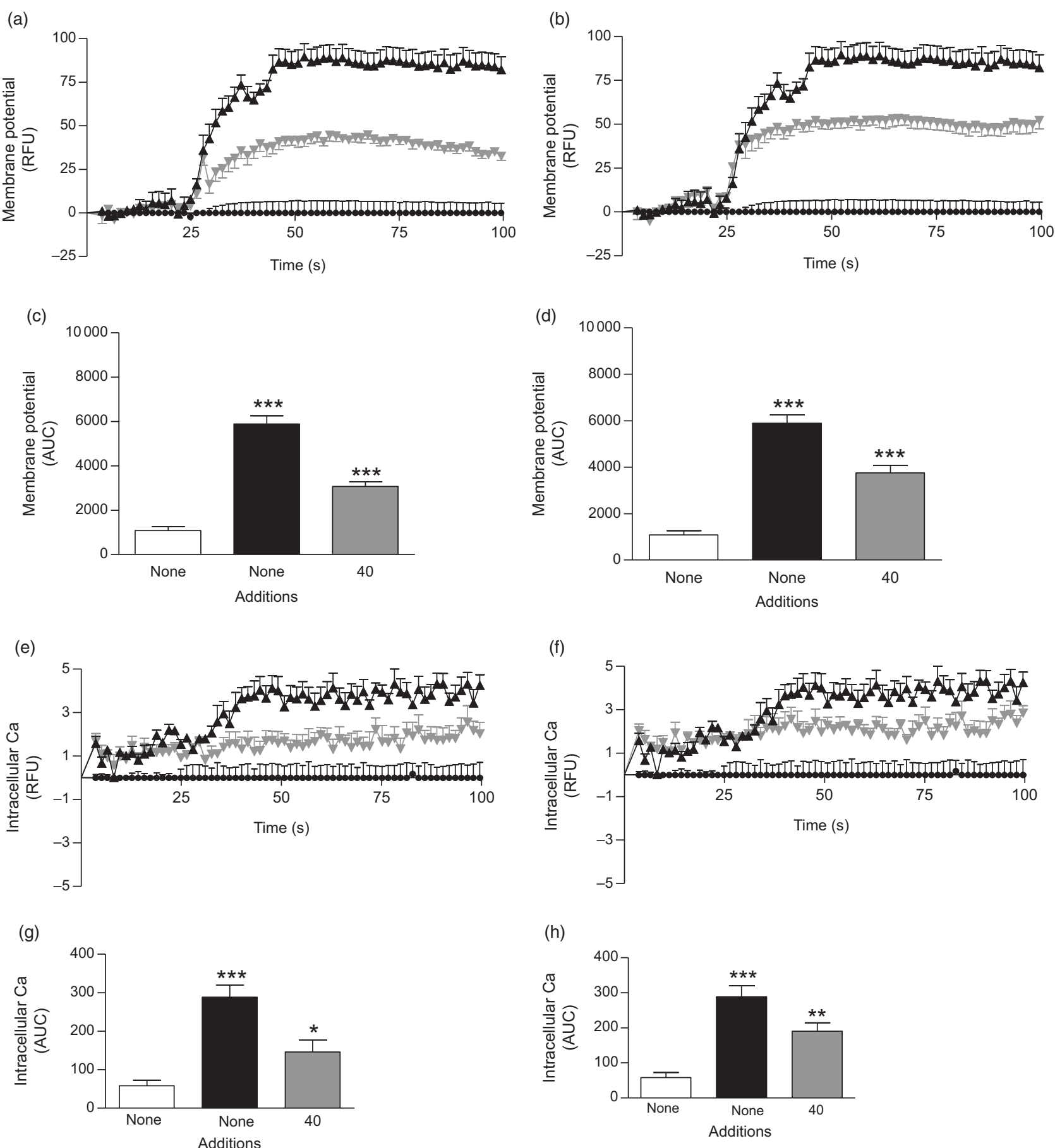

Fig. 4. Effects of ethanol extract and butanol fraction of Spirulina platensis on (a-d) membrane potential and (e-h) intracellular calcium in BRIN-BD11 cells expressed as relative fluorescence units (RFU) and respective AUC. Values are means with their standard errors, $n 6$ for membrane potential and intracellular calcium. ${ }^{\star \star \star} P<0.001$ compared with $5.6 \mathrm{~mm}$ glucose alone. (a and c) $\rightarrow-, \square, 5.6 \mathrm{~mm}$ glucose; $\leftarrow$, $\square, 5.6 \mathrm{~mm}$ glucose $+\mathrm{KCl}(30 \mathrm{~mm}) ;-, \square, 5.6 \mathrm{~mm}$ glucose + ethanol extract $(40 \mu \mathrm{g} / \mathrm{ml})$. (b and d) $\rightarrow$, $\square, 5.6 \mathrm{~mm}$ glucose; $\_$, $\square, 5.6 \mathrm{~mm}$ glucose $+\mathrm{KCl}(30 \mathrm{~mm}) ;-, \square, 5.6 \mathrm{~mm}$ glucose + butanol fraction $(40 \mu \mathrm{gg} / \mathrm{ml})$. (e and g) $\rightarrow, \square, 5.6 \mathrm{~mm}$ glucose; $\_-, \square, 5.6 \mathrm{~mm}$ glucose $+10 \mathrm{~mm}$ alanine; $-\succ, \square, 5.6 \mathrm{~mm}$ glucose + ethanol extract $(40 \mu \mathrm{g} / \mathrm{ml})$. (f and h) $\rightarrow-, \square, \square .6 \mathrm{~mm}$ glucose; $\leftarrow, \square, 5.6 \mathrm{~mm}$ glucose $+10 \mathrm{~mm}$ alanine; $-, \square, 5.6 \mathrm{~mm}$ glucose + butanol fraction $(40 \mu \mathrm{g} / \mathrm{ml})$.

other previously identified compounds in $S$. platensis such as zeaxanthin, astaxanthin, $p$-coumaric acid and apigenin ${ }^{(38,39)}$. The concentrations of nutritional chemical characterisation of S. platensis are listed in Table 2.

\section{Discussion}

S. platensis has been reported recently to exhibit antihyperglycaemic effects, but the mechanism of action was not elucidated ${ }^{(23-25)}$. This study has examined the insulinotropic effects of $S$. platensis 
(a)
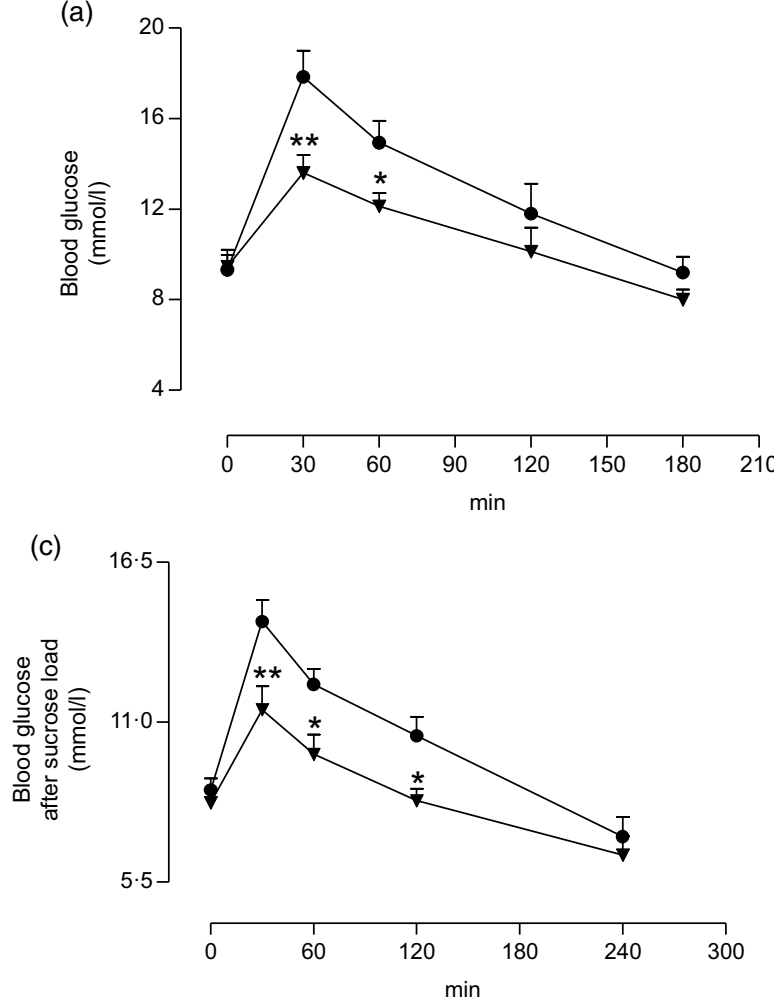

(e)

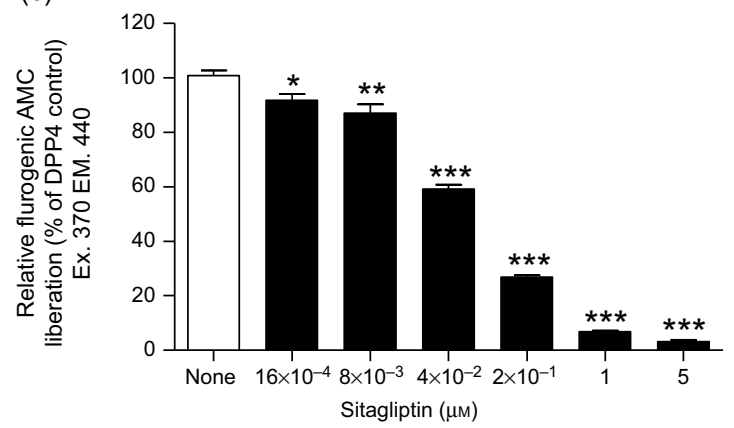

(b)

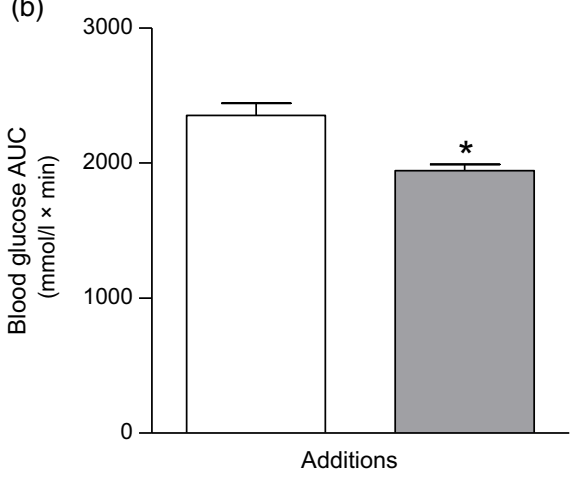

(d)

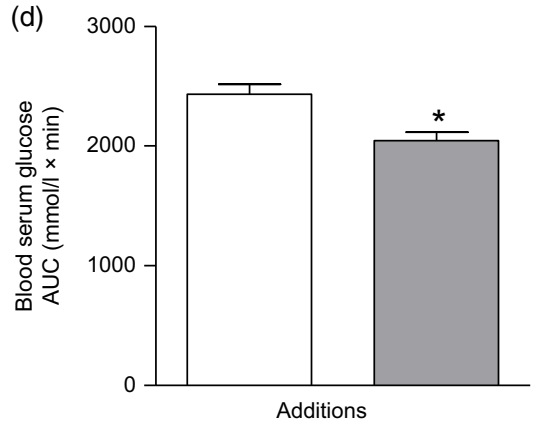

(f)

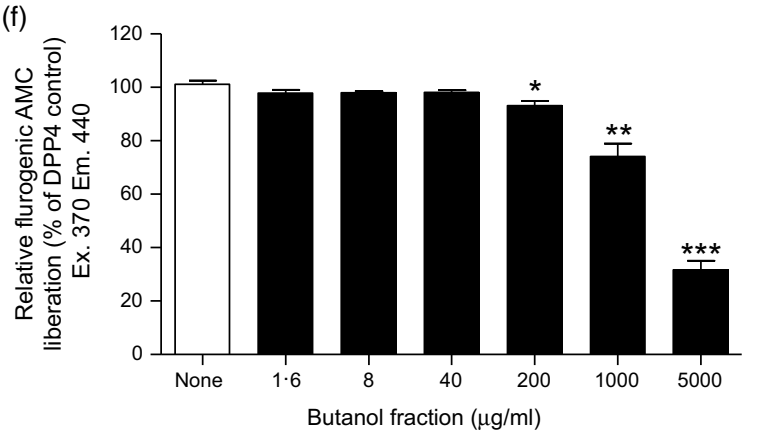

Fig. 5. Effects of butanol fraction of Spirulina platensis on ( $a$ and b) glucose tolerance (GTT), ( $c$ and d) serum glucose after sucrose load (SGASL) in type 2 diabetic rats and (e and f) DPP-IV activity in vitro. Rats were fasted for 12 and $24 \mathrm{~h}$ and administered glucose or sucrose solution (2.5 $\mathrm{g} / \mathrm{kg}$ body weight) by oral administration in presence or absence of butanol fraction of $S$. platensis ( $250 \mathrm{mg} / \mathrm{kg}$ body weight). Sitagliptin was used as established DPP-IV inhibitor. Values are means with their standard errors represented by vertical bars $\left(n 6\right.$, for GTT and SGASL and $n 3$ for DPP-IV). ${ }^{*} P<0.05$, ${ }^{* *} P<0.01$ and ${ }^{* * *} P<0.001$ compared with control. (a and $\left.\mathrm{c}\right) \rightarrow$ - Control; $\rightarrow$, butanol fraction (250 mg/kg). (b and d) $\square$, Control; $\square$, butanol fraction (250 mg/kg). (e) $\square$, Control; $\square$, sitagliptin ( $\mu \mathrm{M})$. (f) $\square$, Control; $\square$, butanol fraction ( $\mu \mathrm{g} / \mathrm{ml})$.

using the perfused rat pancreas, isolated mouse islets and the clonal BRIN-BD11 $\beta$-cell line. The results suggest that the antihyperglycaemic effects are partly mediated through stimulating the insulin secretion from pancreatic $\beta$-cells ${ }^{(27)}$, which is further supported by observation of incremental increases in serum and pancreatic insulin after $28 \mathrm{~d}$ of chronic treatment.

Both the ethanol extract and butanol fraction dose-dependently enhanced insulin release from isolated islets and clonal BRIN-BD11 cells. The butanol fraction was more insulinotropic than the ethanol extract. Likewise, the butanol fraction exerted substantial insulin release from perfused rat pancreas. Non-toxic concentrations of $S$. platensis were used to examine mechanisms underlying stimulation of insulin secretion in the absence and presence of known modulators of $\beta$-cell function. Sulfonylureas are known to act by closing $\mathrm{K}_{\mathrm{ATP}}$ channels, depolarising the plasma membrane, as induced by $30 \mathrm{~mm} \mathrm{KCl}$, and stimulating $\mathrm{Ca}^{2+}$ entry by activation of voltage-dependent $\mathrm{Ca}$ channels ${ }^{(26,40)}$. S. platensis stimulated insulin release enhanced by tolbutamide and $\mathrm{KCl}(30 \mathrm{~mm})$, suggesting its ability to potentiate insulin secretion via other pathways such as the adenylate cyclase/cAMP or the phosphatidylinositol pathway, or as a direct effect on exocytosis ${ }^{(26)}$. S. platensis also clearly stimulated $\beta$-cells via its effects on $\mathrm{Ca}^{2+}$ ion channels. Thus, diazoxide, a $\mathrm{K}_{\mathrm{ATP}}{ }^{-}$ channel opener ${ }^{(41)}$, inhibited the insulin-releasing effects of both the extract and fraction. This suggests that $S$. platensis closes $\mathrm{K}_{\mathrm{ATP}}$ channels to induce insulinotropic action. Furthermore, the L-type voltage-dependent $\mathrm{Ca}^{2+}$ channel blocker, verapamil, ${ }^{(42)}$ also reduced the insulin-releasing effects of $S$. platensis. This suggests 
(a)

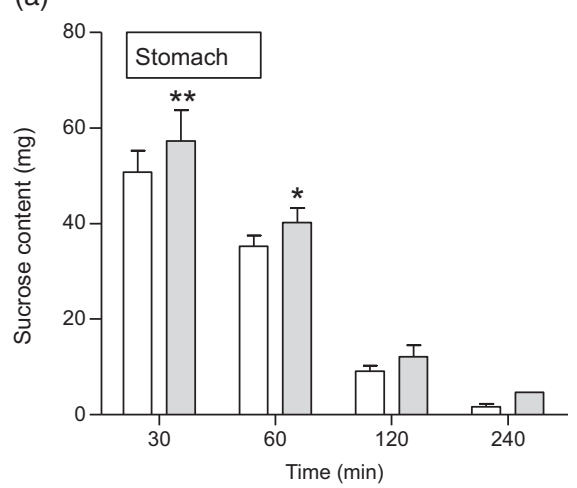

(c)

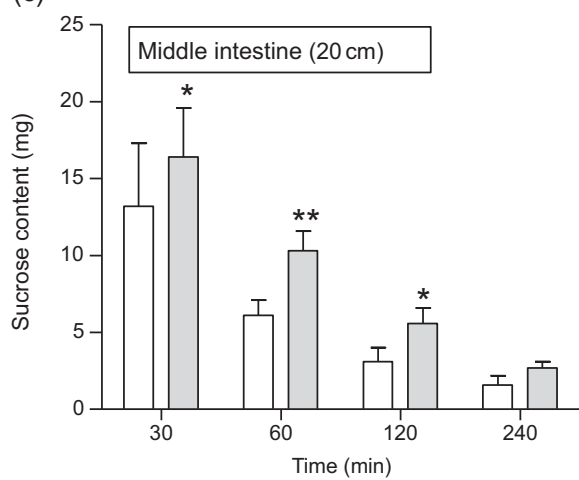

(e)

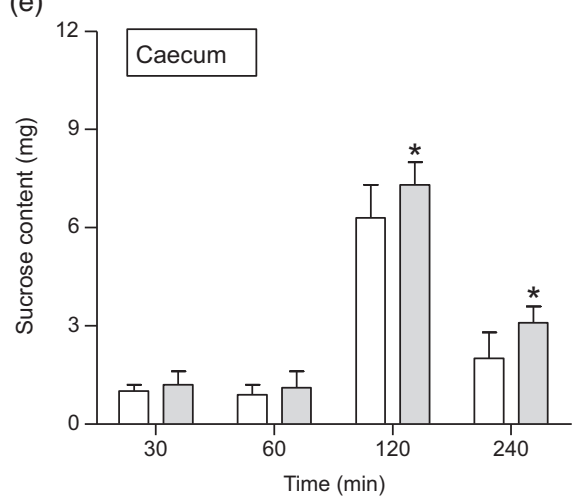

(b)

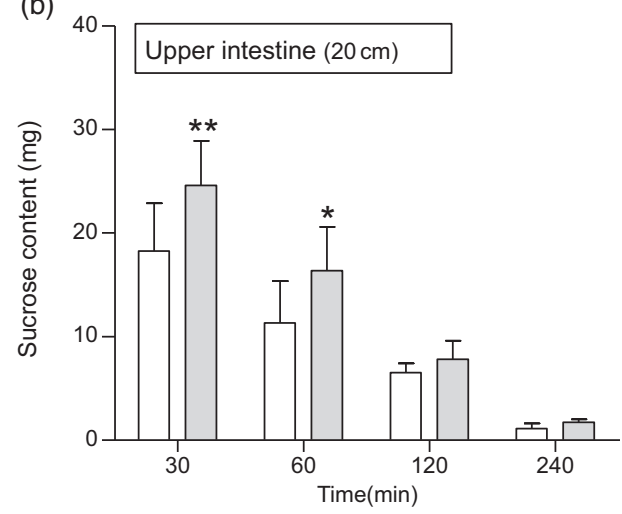

(d)

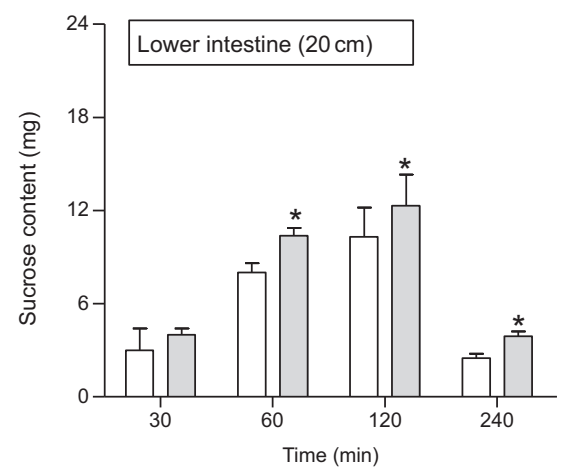

(f)

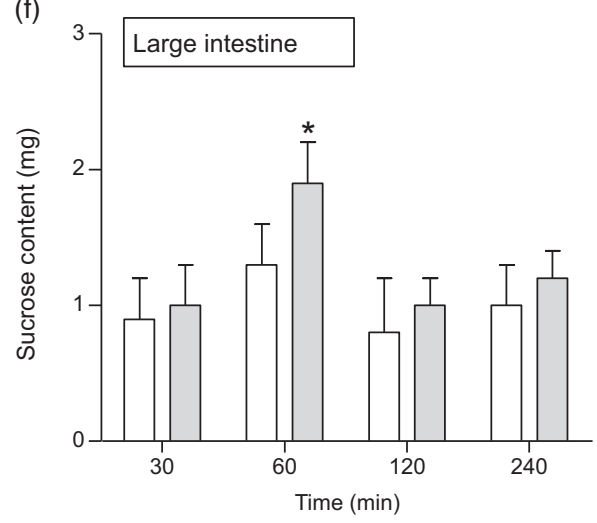

Fig. 6. Effects of butanol fraction of Spirulina platensis on (a-f) gastrointestinal sucrose content after oral sucrose loading in type 2 diabetic rats. Type 2 diabetic rats were fasted for $24 \mathrm{~h}$ prior to the oral administration of sucrose solution $(2.5 \mathrm{~g} / \mathrm{kg}$ body weight) in the presence (treated group) or absence of (control group) butanol fraction of $S$. platensis $\left(250 \mathrm{mg} / \mathrm{kg}\right.$ body weight). Values are means with their standard errors represented by vertical bars $(n 6)$. ${ }^{*} P<0.05$ and ${ }^{\star *} P<0.01$ compared with type 2 diabetic control rats. (a-f) $\square$, Control; $\square$, butanol fraction $(250 \mathrm{mg} / \mathrm{kg}$ ).

a dependency on $\mathrm{Ca}^{2+}$ channel to induce insulin release. Similar intracellular $\mathrm{Ca}^{2+}$ dependency was found in BRIN-BD11 cells, where $S$. platensis increased insulin release, which was inhibited by the L-channel blocker verapamil. Furthermore, studies with BRIN BD11 cells showed $S$. platensis induced membrane depolarisation and increased $\left[\mathrm{Ca}^{2+}\right]_{\mathrm{i}}$.

The insulin-releasing effects of $S$. platensis were also markedly increased by the phosphodiesterase inhibitors isobutyl-methyl xanthine and theophylline implicating involvement of the cAMP pathway ${ }^{(43)}$. Recent studies have shown that use of S. platensis in asthma as adjunct therapy has improved the condition significantly ${ }^{(44)}$. The anti-asthmatic actions have been attributed to elevation of cAMP in bronchial smooth muscle cells, promoting airway relaxation and blocking replication of smooth muscle cells ${ }^{(45)}$. Overall, these results indicate that the polar solvents ethanol and butanol contain active molecules of $S$. platensis that exert multiple effects on the $\beta$-cells mediated most importantly via ion channels.

DPP-IV is an enzyme that metabolises incretin hormones and as a result terminate the insulin-releasing and glucose-lowering actions of both glucagon-like peptide 1 and glucose-dependent insulinotropic polypepide ${ }^{(46)}$. DPP-IV inhibitors have been developed to enhance endogenous incretin action and treat $\mathrm{T}_{2} \mathrm{DM}^{(47)}$. The two incretin hormones have been shown to have multiple action by increasing pancreatic insulin secretion and reducing glucagon secretion ${ }^{(46)}$. In the present study, $S$. platensis significantly $(P<0.05, P<0.01$ and $P<0.001)$ inhibited DPP-IV 
(a)

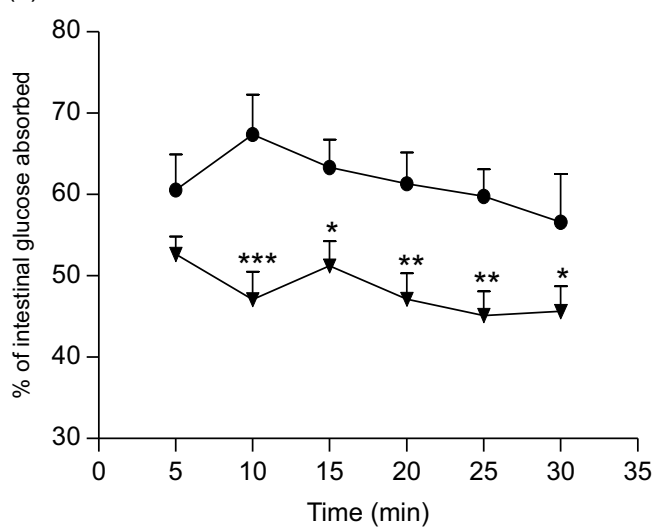

(c)

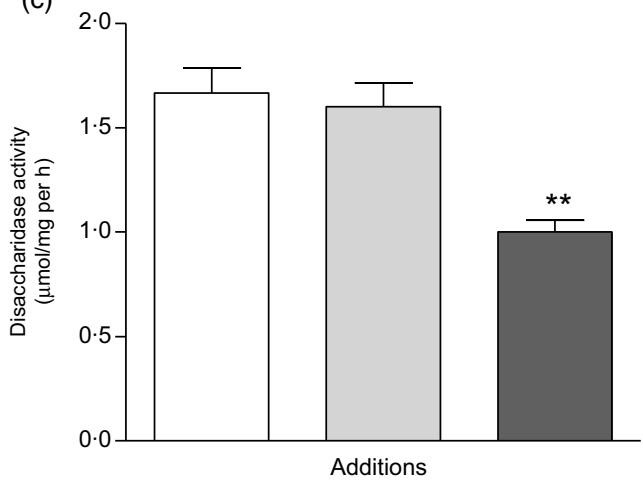

(b)

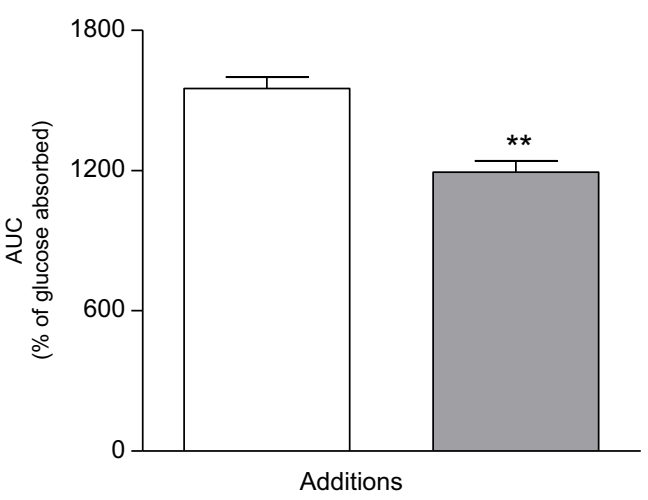

(d)

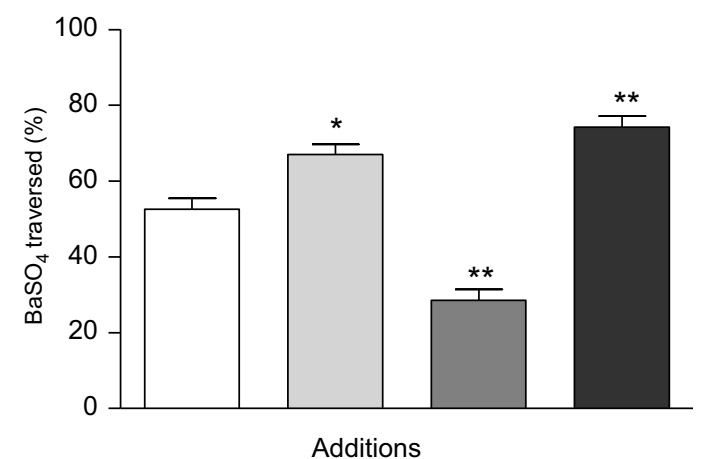

Fig. 7. Effects of butanol fraction of Spirulina platensis on ( $a$ and b) intestinal glucose absorption, (c) disaccharidase enzyme activity and (d) gastrointestinal motility (by $\mathrm{BaSO}_{4}$ traversed) in non-diabetic rats. Rats were fasted for $36 \mathrm{~h}$, and intestine was perfused with glucose (54 $\left.\mathrm{g} / \mathrm{l}\right)$ in the presence (treated group) or absence of (control group) butanol fraction of $S$. platensis $(10 \mathrm{mg} / \mathrm{ml})$. BaSO 4 was administered at $60 \mathrm{~min}$ following oral feeding of $S$. platensis. Acarbose (200 mg/kg); and loperamide (5 mg/ $\mathrm{kg})$ and sennoside $(10 \mathrm{mg} / \mathrm{kg})$ were used as positive controls for determinations of disaccharidase activity and gastrointestinal motility, respectively. Values are means with their standard errors represented by vertical bars $(n 8) .{ }^{*} P<0.05,{ }^{* *} P<0.01$ and ${ }^{* * *} P<0.001$ compared with controls. (a) $\rightarrow-$, Control; $\rightarrow-$, butanol fraction $(250$ $\mathrm{mg} / \mathrm{kg}$ ). (b) $\square$, Control; $\square$, butanol fraction (250 mg/kg). (c) $\square$, Control; $\square$, butanol fraction (250 mg/kg); $\square$, acarbose (200 mg/kg). (d) $\square$, , Control; $\square$, butanol fraction $(250 \mathrm{mg} / \mathrm{kg}) ; \square$, loperamide $(5 \mathrm{mg} / \mathrm{kg}) ; \quad$, sennoside $(10 \mathrm{mg} / \mathrm{kg})$.

Table 1. Long-term effects of the butanol fraction of Spirulina platensis on blood glucose, plasma insulin, pancreatic insulin content and other parameters in type 2 diabetic rats after a 28-d study $+(n 8)$

(Mean values with their standard errors)

\begin{tabular}{|c|c|c|c|c|c|c|c|c|}
\hline \multirow[b]{3}{*}{ Parameters } & \multicolumn{4}{|c|}{$0 \mathrm{~d}$} & \multicolumn{4}{|c|}{$28 d$} \\
\hline & \multicolumn{2}{|c|}{ Control } & \multicolumn{2}{|c|}{ Butanol fraction } & \multicolumn{2}{|c|}{ Control } & \multicolumn{2}{|c|}{ Butanol fraction } \\
\hline & Mean & SEM & Mean & SEM & Mean & SEM & Mean & SEM \\
\hline Glucose (mmol/l) & $9 \cdot 71$ & 1.41 & 9.53 & $1 \cdot 27$ & $9 \cdot 67$ & 1.45 & $7 \cdot 31^{*}$ & $1 \cdot 17$ \\
\hline Plasma insulin (ng/ml) & 0.47 & 0.19 & 0.48 & 0.29 & 0.46 & 0.18 & $0.67^{\star}$ & 0.15 \\
\hline Pancreatic insulin $(\mathrm{nmol} / \mathrm{g})$ & - & & - & & 0.81 & 0.15 & $1 \cdot 10^{\star}$ & 0.11 \\
\hline Liver glycogen $(\mathrm{g} / 100 \mathrm{~g})$ & - & & - & & 1.45 & 0.22 & $2 \cdot 26^{\star}$ & 0.30 \\
\hline Total cholesterol (mmol/l) & - & & - & & 3.53 & 0.20 & $2 \cdot 60^{\star}$ & 0.12 \\
\hline $\mathrm{HDL}(\mathrm{mmol} / \mathrm{l})$ & - & & - & & $2 \cdot 41$ & 0.15 & $3 \cdot 15^{\star}$ & 0.12 \\
\hline LDL (mmol/l) & - & & - & & 2.05 & 0.23 & $0 \cdot 75^{\star *}$ & 0.16 \\
\hline
\end{tabular}

${ }^{*} P<0.05$ and ${ }^{* *} P<0.01$ compared with type 2 diabetic control rats.

† Butanol fraction of $S$. platensis ( $250 \mathrm{mg} / \mathrm{kg}$ body weight) or only saline (control) was administered orally to rats for $28 \mathrm{~d}$.

enzyme activity, indicating that butanol fraction can enhance endogenous glucagon-like peptide 1 and glucose-dependent insulinotropic polypepide activity. A recent study has shown that flavonol glycosides from the seeds of Lens culinaris Medikus (Fabaceae) inhibited DPP-IV enzyme activity in the dose-dependent manner ${ }^{(48)}$. Therefore, it is anticipated that the same phytochemical constituents of $S$. platensis may be responsible for the observed DPP-IV inhibitory activity effect.

Administration of S. platensis significantly lowered blood glucose and improved glucose tolerance in T2DM rats. The butanol fraction also significantly inhibited glucose absorption during gut perfusion. As anticipated, significant amounts of unabsorbed 


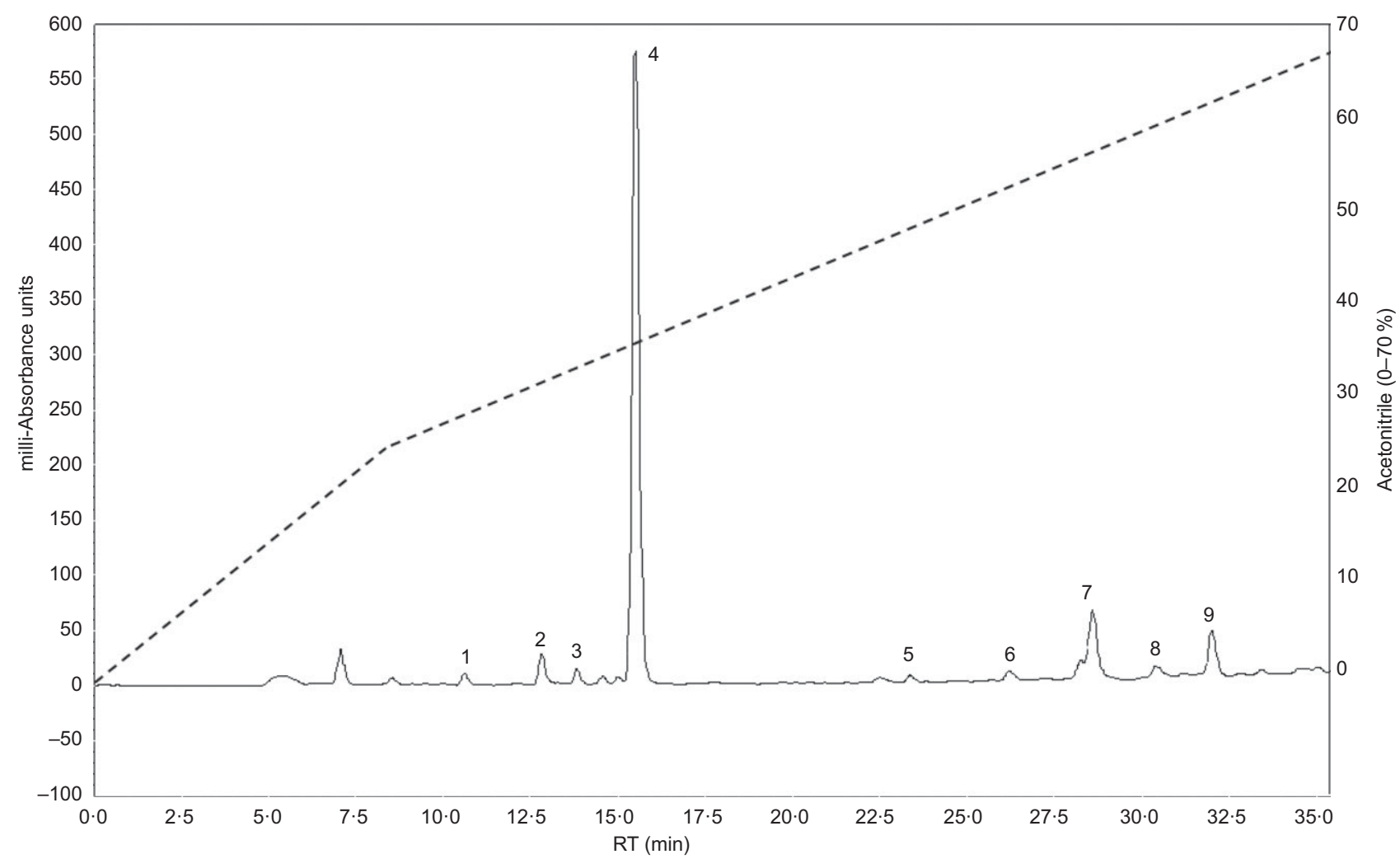

Fig. 8. Representative HPLC profile of butanol fraction of Spirulina platensis using analytical C-18 column over the period of acetonitrile. The column was equilibrated with $0.1 \%(\mathrm{v} / \mathrm{v})$ trifluoroacetic acid/water at flow rate of $1.0 \mathrm{ml} / \mathrm{min}$. The concentration of the eluting solution was raised using linear gradients from 0 to $20 \%$ acetonitrile over $10 \mathrm{~min}$, to $70 \%$ over $25 \mathrm{~min}$. Details of peaks corresponding to butanol fraction are presented in the chromatogram. UV detection was set at 254 and $360 \mathrm{~nm}$, and $1 \mathrm{mg} / \mathrm{ml} \mathrm{sample} \mathrm{was} \mathrm{injected} \mathrm{each} \mathrm{run.} \mathrm{Peaks} \mathrm{1-9} \mathrm{of} \mathrm{unknown} \mathrm{compounds} \mathrm{were} \mathrm{detected} \mathrm{at} \mathrm{different} \mathrm{retention} \mathrm{times} \mathrm{(RT).}$

Table 2. Major compounds identified by reversed-phase-HPLC of the butanol fraction of Spirulina platensis

\begin{tabular}{llcc}
\hline Peaks & Compounds & $\mathrm{RT}(\mathrm{min})$ & Concentration $(\mu \mathrm{g} / \mathrm{ml})$ \\
\hline 1 & Siphonein & $10 \cdot 3$ & $20 \cdot 6$ \\
2 & Zeaxanthin & $12 \cdot 6$ & 30.5 \\
3 & Astaxanthin & $13 \cdot 0$ & $17 \cdot 8$ \\
4 & Unidentified carotenoids & $15 \cdot 3$ & $122 \cdot 4$ \\
5 & Catechin & 23.5 & $15 \cdot 6$ \\
6 & Pheophytin A & $26 \cdot 2$ & $15 \cdot 6$ \\
7 & $p$-Coumaric acid & $29 \cdot 0$ & 51.3 \\
8 & $\beta$-Carotene & $30 \cdot 8$ & 22.1 \\
9 & Apigenin & $32 \cdot 4$ & 29.7 \\
\hline
\end{tabular}

$\mathrm{RT}$, retention time.

sucrose were found in postprandial state throughout the gut. This postprandial effect may be related to the interference of intestinal glucose absorption ${ }^{(33)}$. The butanol fraction of $S$. platensis did not inhibit intestinal disaccharidase enzyme activity, and thus inhibition of digestion of carbohydrate is not involved in its mechanism of antihyperglycaemic action. However, increased GI motility, examined using $\mathrm{BaSO}_{4}$ milk, may inhibit carbohydrate absorption in the gut. Dietary fibres reduce postprandial food transit time in the GI tract ${ }^{(49)}$; thus, shorter time is available for the carbohydrate absorption ${ }^{(50)}$, and therefore postprandial hyperglycaemia is reduced. High sucrose content in the GI tract indicates reduced sucrose digestion. As a result, a significantly higher concentration of sucrose reaches to the large intestine and caecum and is excreted. S. platensis reduced postprandial sucrose absorption and enhanced GI motility, possibly by forming glucose-fibre complexes that reduce post prandial transit time or gastric emptying time.

A recent study using $S$. platensis reported potential protective activity against fat induced apoptosis and decreasing intestinal cholesterol absorption ${ }^{51,52)}$. However, in the present chronic study, administration of butanol fraction of $S$. platensis for $28 \mathrm{~d}$ in type 2 diabetic rats significantly increased liver glycogen content and HDL, while it reduced LDL substantially. Interestingly, chronic treatment also enhanced plasma insulin and pancreatic insulin content in type 2 diabetic rats. Therefore, the stimulation of insulin release from $\beta$-cells as well as insulin action is possibly thereby co-related with the improvement of hepatic glucose uptake.

The phytochemical screening of $S$. platensis using reversedphase HPLC revealed the presence of several phenolic acids like $p$-coumaric acid and other bioactive molecules such as pheophytin A, catechin, zeaxanthin, astaxanthin, apigenin and carotenoid pigments including $\beta$-carotene. This composition is in general agreement with the previous research ${ }^{(38,39)}$. Recent studies also claim that these compounds have antioxidant properties, trigger insulin secretion and have antihyperglycaemic activity ${ }^{(53-55)}$.

In conclusion, this study has shown that ethanol extract of $S$. platensis and its butanol fraction exert prominent stimulatory 
effects on insulin secretion from $\beta$-cells via physiological pathways. In vivo studies in T2DM rats indicate that the butanol fraction decreased blood glucose, increased gut motility, reduced glucose absorption in GIT and improved both plasma and pancreatic insulin levels. S. platensis contains important phytochemicals and valuable micro/macronutrients, consistent with the use of this microalgae as a prophylactic or dietary supplement in the treatment of diabetes.

\section{Acknowledgements}

The authors would like to thank the School of Biomedical Sciences and members of the Diabetes Research Group for providing access to their laboratory and the use of facilities to carry out this research.

The present study was supported by the Ulster University Strategic Research Funding and award of Vice Chancellor's research studentship to P. A.

Y. H. A. A.W. and P. R. F. were responsible for the conception and design of research and also contributed equally to the supervision of the study. P. A., J. M. A. H. and S. A. performed the experiments. P. A and S. A. analysed the data; P. A. and J. M. A. H. interpreted the results of experiments; P. A. prepared the figures; P. A. and S. A. drafted the manuscript; Y. H. A. A. W., P. R. F. and P.A. edited the revised manuscript; all authors approved the final version of the manuscript.

The authors declare that there are no conflicts of interest.

\section{References}

1. Brand-Miller J, McMillan-Price J, Steinbeck K, et al. (2009) Dietary glycemic index: health implications. J Am Coll Nutr 28, 446S-449S.

2. Peters SA, Huxley RR \& Woodward M (2014) Diabetes as risk factor for incident coronary heart disease in women compared with men: a systematic review and meta-analysis of 64 cohorts including 858,507 individuals and 28,203 coronary events. Diabetologia 57, 1542-1551.

3. Arzoo SH, Chattopadhyay K, Banerjee S, et al. (2018) Synergistic improved efficacy of Gymnadenia orchidis root Salep and pumpkin seed on induced diabetic complications. Diabetes Res Clini Prac 146, 278-288.

4. Whitmer RA, Karter AJ, Yaffe K, et al. (2009) Hypoglycemic episodes and risk of dementia in older patients with type 2 diabetes mellitus. JAMA 301, 1565-1572.

5. Simo R \& Hernandez C (2002) Treatment of diabetes mellitus: general goals, and clinical practice management. Rev Esp Cardiol 55, 845-860.

6. Ghadge AA \& Kuvalekar AA (2017) Controversy of oral hypoglycemic agents in type 2 diabetes mellitus: novel move towards combination therapies. Diabetes Metab Syndr 11, S5-S13.

7. Stein SA, Lamos EM \& Davis SN (2013) A review of the efficacy and safety of oral antidiabetic drugs. Expert Opin Drug Saf $\mathbf{1 2}$, $153-175$.

8. Singh A \& Dwivedi S (2017) Study of adverse drug reactions in patients with diabetes attending a tertiary care hospital in New Delhi, India. Indian J Med Res 145, 247-249.

9. Naja F, Alameddine M, Itani L, et al. (2015) The use of complementary and alternative medicine among Lebanese adults: results from a national survey. Evid Based Complement Alternat Med 2015, 682397-682397.

10. Medagama AB, Bandara R, Abeysekera RA, et al. (2014) Use of Complementary and Alternative Medicines (CAMs) among type 2 diabetes patients in Sri Lanka: a cross sectional survey. BMC Complement Altern Med 14, 374.

11. Lunyera J, Wang D, Maro V, et al. (2016) Traditional medicine practices among community members with diabetes mellitus in Northern Tanzania: an ethnomedical survey. BMC Complement Altern Med 16, 282-282.

12. Jung M, Park M, Lee HC, et al. (2006) Antidiabetic agents from medicinal plants. Curr Med Chem 13, 1203-1218.

13. Ji C, Han J, Zhang J, et al. (2018) Omics-prediction of bioactive peptides from the edible cyanobacterium Arthrospira platensis proteome. J Sci Food Agric 98, 984-990.

14. Ibanez E \& Cifuentes A (2013) Benefits of using algae as natural sources of functional ingredients. J Sci Food Agric 93, 703-709.

15. Shahidi F \& Ambigaipalan P (2015) Novel functional food ingredients from marine sources. Curr Opin Food Sci 2, 123-129.

16. Sheih IC, Fang TJ, Wu TK, et al. (2010) Anticancer and antioxidant activities of the peptide fraction from algae protein waste. $J$ Agric Food Chem 58, 1202-1207.

17. Vo T-S, Ryu B \& Kim S-K (2013) Purification of novel antiinflammatory peptides from enzymatic hydrolysate of the edible microalgal Spirulina maxima. J Funct Foods 5, 1336-1346.

18. Samarakoon KW, O-Nam K, Ko J-Y, et al. (2013) Purification and identification of novel angiotensin-I converting enzyme (ACE) inhibitory peptides from cultured marine microalgae (Nannochloropsis oculata) protein hydrolysate. J Appl Phycol 25, 1595-1606.

19. Pankaj PP (2015) Efficacy of Spirulina platensis in improvement of the reproductive performance and easing teratogenicity in hyperglycemic albino mice. Indian J Pharmacol 47, 430-435.

20. Hosseini SM, Khosravi-Darani K \& Mozafari MR (2013) Nutritional and medical applications of spirulina microalgae. Mini Rev Med Chem 13, 1231-1237.

21. Abdel-Daim MM, Abuzead SM \& Halawa SM (2013) Protective role of Spirulina platensis against acute deltamethrin-induced toxicity in rats. PLOS ONE 8, e72991.

22. Deng R \& Chow TJ (2010) Hypolipidemic, antioxidant, and antiinflammatory activities of microalgae Spirulina. Cardiovasc Ther 28, e33-45.

23. Oriquat GA, Ali MA, Mahmoud SA, et al. (2018) Improving hepatic mitochondrial biogenesis as a postulated mechanism for the antidiabetic effect of Spirulina platensis in comparison with metformin. Appl Physiol Nutr Metab 44, 357-364.

24. Nasirian F, Mesbahzadeh B, Maleki SA, et al. (2017) The effects of oral supplementation of Spirulina platensis microalgae on hematological parameters in streptozotocin-induced diabetic rats. Am J Transl Res 9, 5238-5244.

25. Nasirian F, Dadkhah M, Moradi-Kor N, et al. (2018) Effects of Spirulina platensis microalgae on antioxidant and anti-inflammatory factors in diabetic rats. Diabetes Metab Syndr Obes 11, 375-380.

26. Hannan JM, Marenah L, Ali L, et al. (2006) Ocimum sanctum leaf extracts stimulate insulin secretion from perfused pancreas, isolated islets and clonal pancreatic beta-cells. J Endocrinol 189, 127-136.

27. Hannan JM, Marenah L, Ali L, et al. (2007) Insulin secretory actions of extracts of Asparagus racemosus root in perfused pancreas, isolated islets and clonal pancreatic beta-cells. J Endocrinol 192, 159-168.

28. Flatt PR \& Bailey CJ (1981) Abnormal plasma glucose and insulin responses in heterozygous lean $(\mathrm{ob} /+)$ mice. Diabetologia 20, 573-577. 
29. Giroix MH, Portha B, Kergoat M, et al. (1983) Glucose insensitivity and amino-acid hypersensitivity of insulin release in rats with non-insulin-dependent diabetes. A study with the perfused pancreas. Diabetes 32, 445-451.

30. Abdel-Wahab YH, Marenah L, Flatt PR, et al. (2007) Insulin releasing properties of the temporin family of antimicrobial peptides. Protein Pept Lett 14, 702-707.

31. Miguel JC, Patterson S, Abdel-Wahab YH, et al. (2004) Timecorrelation between membrane depolarization and intracellular calcium in insulin secreting BRIN-BD11 cells: studies using FLIPR. Cell Calcium 36, 43-50.

32. Duffy NA, Green BD, Irwin N, et al. (2007) Effects of antidiabetic drugs on dipeptidyl peptidase IV activity: nateglinide is an inhibitor of DPP IV and augments the antidiabetic activity of glucagon-like peptide-1. Eur J Pharmacol 568, 278-286.

33. Hannan JM, Ali L, Khaleque J, et al. (2012) Antihyperglycaemic activity of Asparagus racemosus roots is partly mediated by inhibition of carbohydrate digestion and absorption, and enhancement of cellular insulin action. Br J Nutr 107, 1316-1323.

34. Goto Y, Yamada K, Ohyama T, et al. (1995) An alpha-glucosidase inhibitor, AO-128, retards carbohydrate absorption in rats and humans. Diabetes Res Clin Pract 28, 81-87.

35. Swintosky J \& Pogonowskawala E (1982) The in-situ rat gut technique. Pharm Int 3, 163-170.

36. Chatterjee T (1993) Handbook of Laboratory Mice and Rats. India: Department of Pharmaceutical Technology, Jadavpur University.

37. Vies JV (1954) Two methods for the determination of glycogen in liver. Biochem J 57, 410-416.

38. Mendiola JA, Marin FR, Hernndez SF, et al. (2005) Characterization via liquid chromatography coupled to diode array detector and tandem mass spectrometry of supercritical fluid antioxidant extracts of Spirulina platensis microalga. $J$ Sep Sci 28, 1031-1038.

39. Moor VJA, Pieme CA, Biapa PCN, et al. (2016) Chemical composition of Spirulina platensis of nomayos-yaounde. Annals Food Sci Technol 17, 524-528.

40. Boyd AE 3rd (1988) Sulfonylurea receptors, ion channels, and fruit flies. Diabetes 37, 847-850.

41. Wang Y, Wang S, Harvat T, et al. (2015) Diazoxide, a K(ATP) channel opener, prevents ischemia-reperfusion injury in rodent pancreatic islets. Cell Transplant 24, 25-36.

42. Weinhaus AJ, Poronnik P, Cook DI, et al. (1995) Insulin secretagogues, but not glucose, stimulate an increase in $\left[\mathrm{Ca}^{2+}\right] \mathrm{i}$ in the fetal rat $\beta$-cell. Diabetes 44, 118-124.
43. Sharp GW (1979) The adenylate cyclase-cyclic AMP system in islets of Langerhans and its role in the control of insulin release. Diabetologia 16, 287-296.

44. Manzon-Reyes LVLA \& Andaya AG (2018) The effects of Spirulina (Arthrospira platensis) dietary supplement as an adjunct therapy for children aged 7-14 years old with asthma: A randomized - double blind placebo controlled clinical trial. $J$ Allergy Clinical Immunol 141, AB208.

45. Billington CK, Ojo OO, Penn RB et al. (2013) cAMP regulation of airway smooth muscle function. Pulm Pharmacol Ther 26, 112-120.

46. Singh AK (2014) Dipeptidyl peptidase-4 inhibitors: novel mechanism of actions. Indian J Endocrinol Metab 18, 753-759.

47. Godinho R, Mega C, Teixeira-de-Lemos E, et al. (2015) The place of dipeptidyl peptidase- 4 inhibitors in type 2 diabetes therapeutics: a "me too" or "the special one" antidiabetic class? J Diabetes Res 2015, 28.

48. Kim BR, Kim HY, Choi I, et al. (2018) DPP-IV inhibitory potentials of flavonol glycosides isolated from the seeds of Lens culinaris: in vitro and molecular docking analyses. Molecules 23, 1998.

49. Burkitt DP, Walker ARP \& Painter NS (1972) Effect of dietary fibre on stools and transit-times, and its role in the causation of disease. Lancet 300, 1408-1411.

50. Holgate AM \& Read NW (1983) Relationship between small bowel transit time and absorption of a solid meal. Influence of metoclopramide, magnesium sulfate, and lactulose. Dig Dis Sci 28, 812-819.

51. Yigit F, Gurel-Gurevin E, Isbilen-Basok B, et al. (2016) Protective effect of Spirulina platensis against cell damage and apoptosis in hepatic tissue caused by high fat diet. Biotech Histochem 91, 182-194.

52. Ku CS, Kim B, Pham TX, et al. (2015) Hypolipidemic effect of a blue-green alga (Nostoc commune) is attributed to its nonlipid fraction by decreasing intestinal cholesterol absorption in C57BL/6J Mice. J Med Food 18, 1214-1222.

53. Sayahi M \& Shirali S (2017) The antidiabetic and antioxidant effects of carotenoids: a review. Asian J Pharm Res Health Care 9, 186-191.

54. Mueller L \& Boehm V (2011) Antioxidant activity of $\beta$-carotene compounds in different in vitro assays. Molecules 16, 10551069.

55. Amalan V, Vijayakumar N, Indumathi D, et al. (2016) Antidiabetic and antihyperlipidemic activity of $p$-coumaric acid in diabetic rats, role of pancreatic GLUT 2: in vivo approach. Biomed Pharmacother 84, 230-236. 